\title{
The position and age of flysch deposits in the Crimea Mountains (Southern Ukraine)
}

\author{
Nestor OSZCZYPKO ${ }^{1, ~ *}$, Andrzej ŚLACZZKA ${ }^{1}$, Ihor BUBNIAK², \\ Barbara OLSZEWSKA ${ }^{3}$ and Małgorzata GARECKA ${ }^{3}$
}

\footnotetext{
1 Jagiellonian University, Institute of Geological Sciences, Gronostajowa 3a, 30-001 Kraków, Poland

2 Ivan Franko National University of Lviv, Geological Faculty, Hrushevsky 4, Lviv 79005, Ukraine

3 Polish Geological Institute - National Research Institute, Skrzatów 1, 31-560 Kraków, Poland
}

Oszczypko, N., Ślączka, A., Bubniak, I., Olszewska, B., Garecka, M., 2017. The position and age of flysch deposits in the Crimean Mountains (Southern Ukraine). Geological Quarterly, 61 (4): 697-722, doi: 10.7306/gq.1359

\begin{abstract}
The Crimean Mountains (CM) are regarded as part of the Alpine-Himalaya orogenic belt related to the collision of the Eurasian and African plates. Our research in the $\mathrm{CM}$ has allowed confirming the existence of at least two flysch formations of different ages: the Taurida Flysch Formation (Upper Triassic/Lower-? Middle Jurassic) and the Sudak Formation (uppermost Jurassic/Lower Cretaceous) in the western and eastern sectors of the CM, respectively. After the Middle Jurassic volcanism, the freshwater claystones with coal-bearing intercalations, as well as local alluvial fan conglomerates were deposited. Then, following the Oxfordian/Kimmeridgian marine transgression, three separated Tithonian/Berriasian carbonate platforms developed: Baydarska, Chatyr-Dag and Demerji/Karabi. At the turn of the Late Jurassic, the deep-water Sudak Basin (eastern sector of the CM) began to develop in the eastern periphery of the Demerii/Karabi carbonate platform. This basin, dominated by turbiditic deposition, was probably connected with the Great Caucasus sedimentary system. Finally, distal flysch sedimentation in the Sudak Basin was followed by debris-flow deposits, with huge blocks of Upper Jurassic limestones. These blocks were derived from destruction of the Karabi carbonate platform. During the Berriasian/Valanginian, the eastern sector of the $\mathrm{CM}$ began to subside. As a result, both carbonate platforms (western CM) and the debris flow fans of the Sudak Basin (eastern CM) were overlain by marly shales and/or distal turbidites. This type of deposition lasted until the Aptian/Albian. In the post-Albian period, the Alushta-Salgir tectonic zone was transformed into a SE-dipping thrust fault with at least $10 \mathrm{~km}$ amplitude of overthrusting.
\end{abstract}

Key words: Ukraine, Crimean Mts., stratigraphy, micropalaeontology, flysch.

\section{INTRODUCTION}

Flysch sediments, known already for more than 150 years (from Dubois de Montpereaux, 1837), play an important role in the geological structure of the Crimean Mts. These deposits were traditionally regarded as the Tauric Flysch of Late Triassic/Early Jurassic age (Muratov et al., 1969; Muratov, 1972). This age has been challenged by Popadyuk and Smirnov (1991), who concluded Early Cretaceous age. This sparked a lively discussion (e.g., Popadyuk et al., 2010, 2013a, b, 2014; Oszczypko et al., 2012b, c) until Sheremet et al. (2014, 2016a), on the basis of calcareous nannoplanton analyses of flysch-like deposits in the eastern sector of the CM, included both the Tauric Formation and the Lower Cretaceous flysch deposits of the eastern sector of the Crimea into the Tauric Group.

\footnotetext{
* Corresponding author, e-mail: nestor.oszczypko@uj.edu.pl Received: July 20, 2016; accepted: March 16, 2017; first published online: May 10, 2017
}

Taking into account our experience in studying the Outer Carpathians flysch, we became interested in the explanation of the controversy related to the Tauric Flysch. With this in mind, we have conducted our studies in the years 2010-2013, during the three short, but intense field work campaings. Our interest has been focused on the following main questions:

- litho- and biostratigraphic studies of the Tauric Flysch;

- its relationships to overlying lithostratigraphic units;

- lateral and longitudinal spatial variability of the Tauric Flysch, especially along the west-east direction.

We started from the locus typicus of the Tauric Flysch: the Alma and Bodrak valleys and along the Black Sea coast, between the Cape of Sarych in the west and the village of Rybache in the east (Oszczypko et al., 2012b, c). Then, we tried to recognize the relationship between the Tauric Flysch and the Jurassic?/Early Cretaceous flysch of the eastern sector of the CM (Oszczypko et al., 2012c).

In Russian publications, the Mesozoic flysch is known as the Tavricheskaya svita, series, group or simply Taurica. We suggest introducing a new term - the Taurida Flysch Formation (TFF), which is more consistent with the formal lithostratigraphic standards, recommending a geographical noun. In this case it will be the Taurida - an ancient Greek name of the Crimean Peninsula. 


\section{GEOLOGICAL SETTING}

The Crimean Mts. are part of the southern, deformed boundary of the East European Platform, located between the Scythian Plate (which belongs to the Eurasian continent) and the Black Sea (Figs. 1 and 2). This mountain chain is $\sim 50 \mathrm{~km}$ wide and $\sim 150 \mathrm{~km}$ long (Figs. 3 and 4; cf. Appendix $1^{*}$ ). It is arch-shaped, with E-W structural trends in the west, and NE-SW in the east. Traditionally, the CM are regarded as the Cimmerian/Alpine orogen (Muratov, 1960, 1969; Koronovsky and Mileev, 1974; Byzova, 1980; Kruglov and Tsypko, 1988; Mileev et al., 1997, 2006, 2009; Nikishin at al., 2015a, c).
First detailed information on tectonic deformations of the Tauric and Eski-Orda series, in the Bodrak Valley, was given by Koronovsky and Mileev (1974). These authors described in places the highly deformed complex, with south-vergent folding and thrusting, related to the Early Cimmerian phase. An interesting view on the structural evolution of the Crimean orogen was presented by Kruglov and Tsypko (1988), who highlighted two Cimmerian orogenic phases: the older ( $\mathrm{Li}-$ assic/Bathonian) one in the NW sector of the CM, and the younger (Valanginian/Hauterivian) one in the SE sector of the $\mathrm{CM}$. The early orogenic phase took place in the outer (external) part of the basin, where the folding of TFF was preceded by pre-folding volcanism. This is well-documented (Kruglov

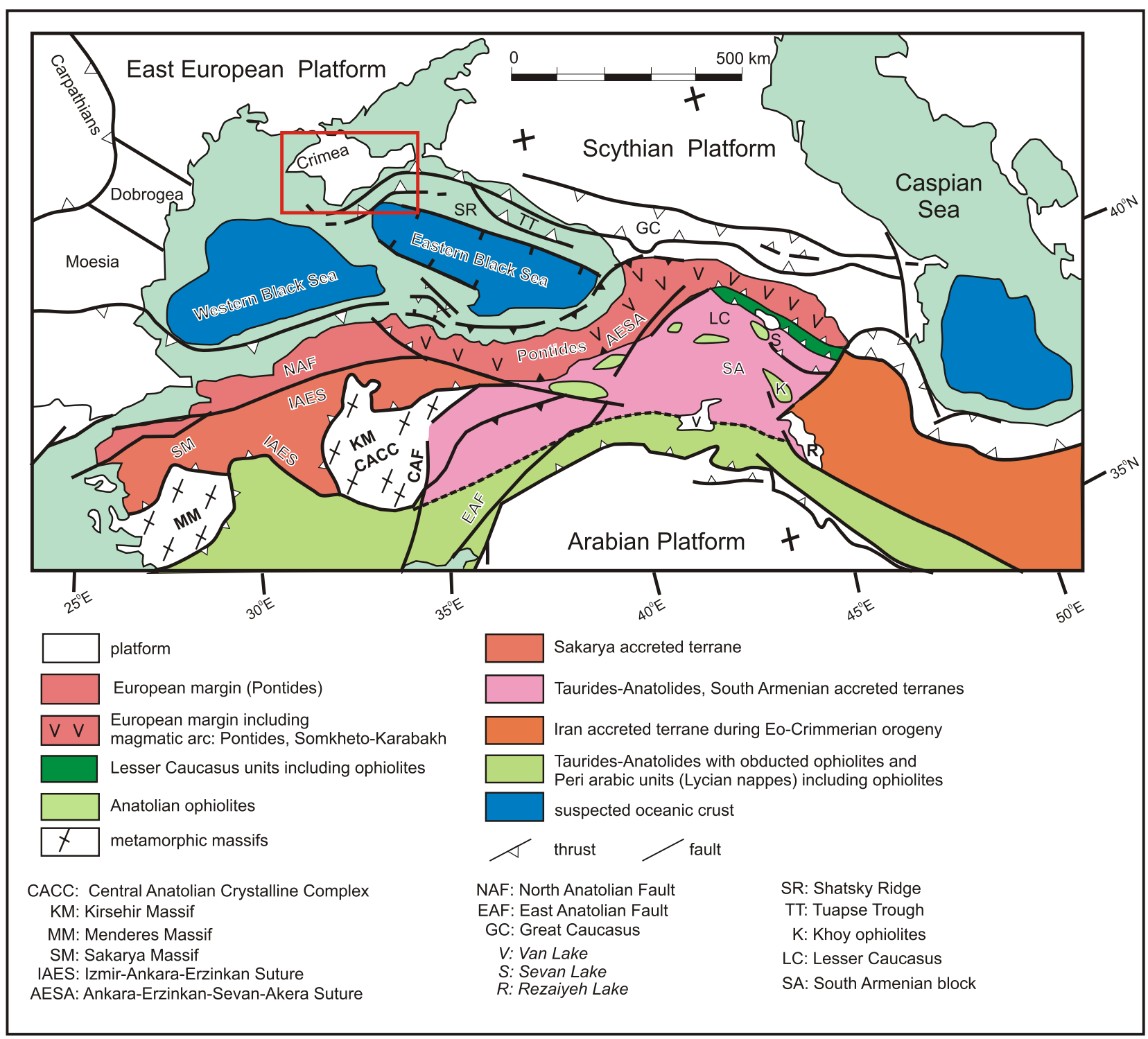

Fig. 1. Structural sketch-map of the Alpine Orogen System of SE Europe and Middle East sensu lato after Sosson at al. (2010), simplified

Position of the Crimea Mts. is shown as a red rectangle

* Supplementary data associated with this article can be found, in the online version, at doi: $10.7306 / \mathrm{gq} .1359$ 


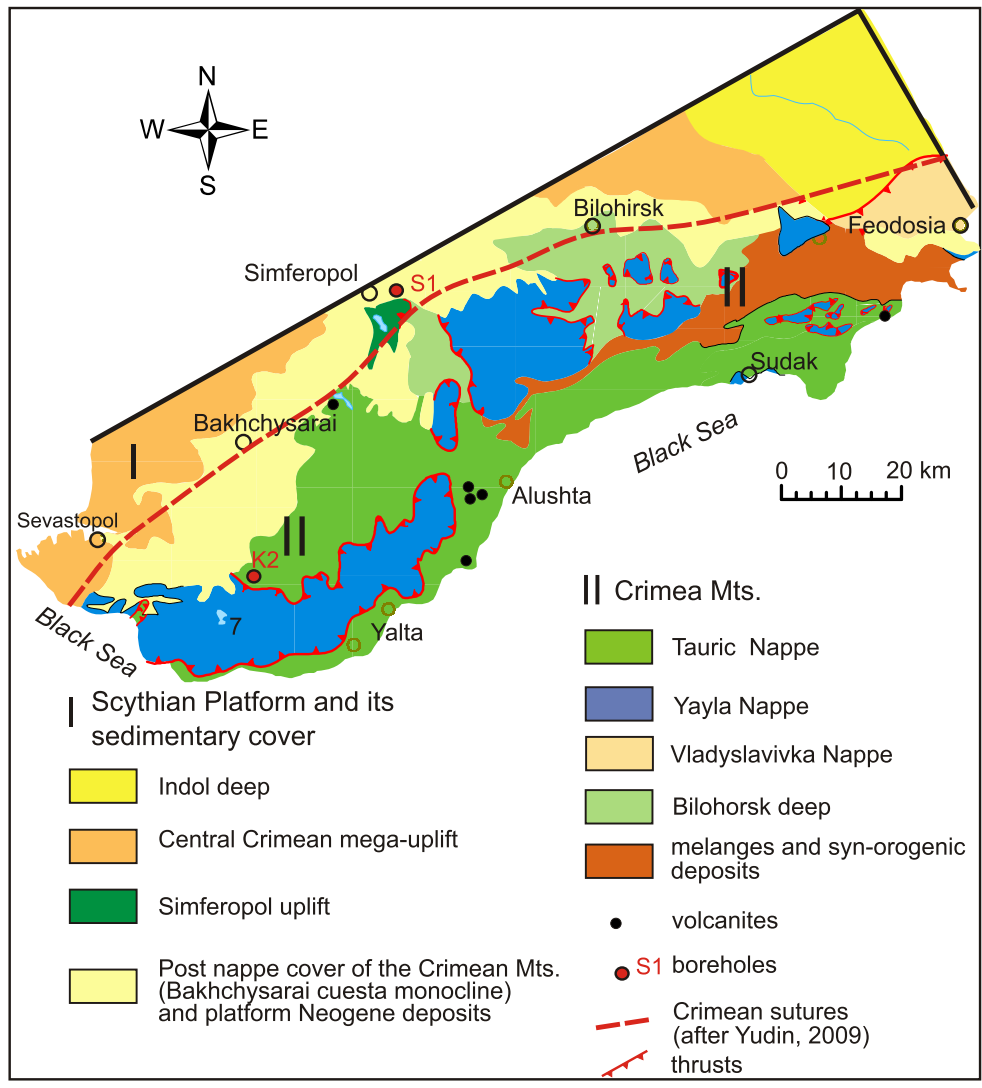

Fig. 2. Tectonic map of the Crimea Mountains (Hurskyi and Kruglov, 2006) and Tsypko, 1988) by results of the Kacha 2 borehole (40 km SW of Simferopol). This borehole drilled to the final depth of $4032 \mathrm{~m}$ revealed intensely folded sediments TFF $\left(T_{3}-J_{1}\right)$ with numerous intrusions (dykes, sills and pillow lavas of diabases, picritic diabases, andesites and basalt-andesites) in the 2270-3930 m depth interval.

Hurskiy and Kruglov (2007) distinguished the following structural complexes:

- autochthonous (Aptian/Albian), fragmentarily preserved in the Salgir and Tonas valleys;

- allochthonous complex with two nappes: lower - the Tauric Nappe, and upper - the Yayla Nappe (carbonate platforms);

- Cenomanian/Eocene post-nappe complex (Fig. 2).

In the Simferopol 1 borehole, beneath the Tauric Nappe, Lower Cretaceous deposits were pierced at a depth of $\sim 4 \mathrm{~km}$ (Yudin, 2005, 2013).

The interpretation of Kruglov and Tsypko (1988) clearly shows that sedimentation of the TFF in the external (NW) part of the basin ended up in the Middle Jurassic, and continued through the Valanginian/Hauterivian in the inner (SE) basin. In the Crimea Basin, this deformation took place in close relation with the begining of the closure of the Neo-Tethys Ocean (Kazmin et al., 2000; Golonka, 2004). However, there was also consequent Alpine deformation (during the Paleogene), related to the Arabia-Eurasia convergence and to the evo-

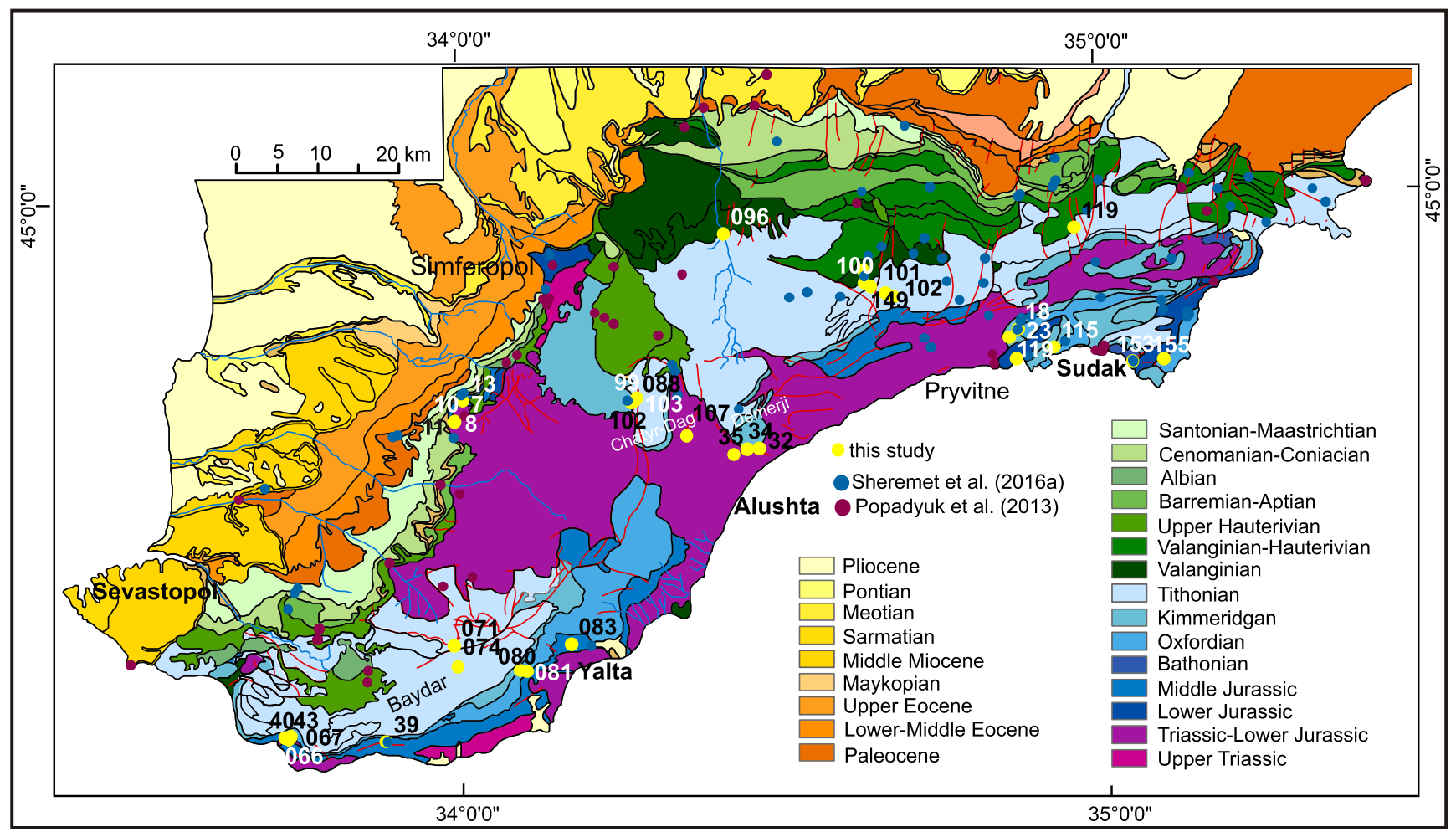

Fig. 3. Simplified geological map of the Crimea Mountains based on Muratov (1960), Pivovarov and Derenyuk (1984) and Popadyuk et al. (2013a), with location of the most recent micropalaeontological data presented by Popadyuk et al. (2013a) and Sheremet et al. (2014, 2016a), and of our study sections (WP) in 2011-2013 


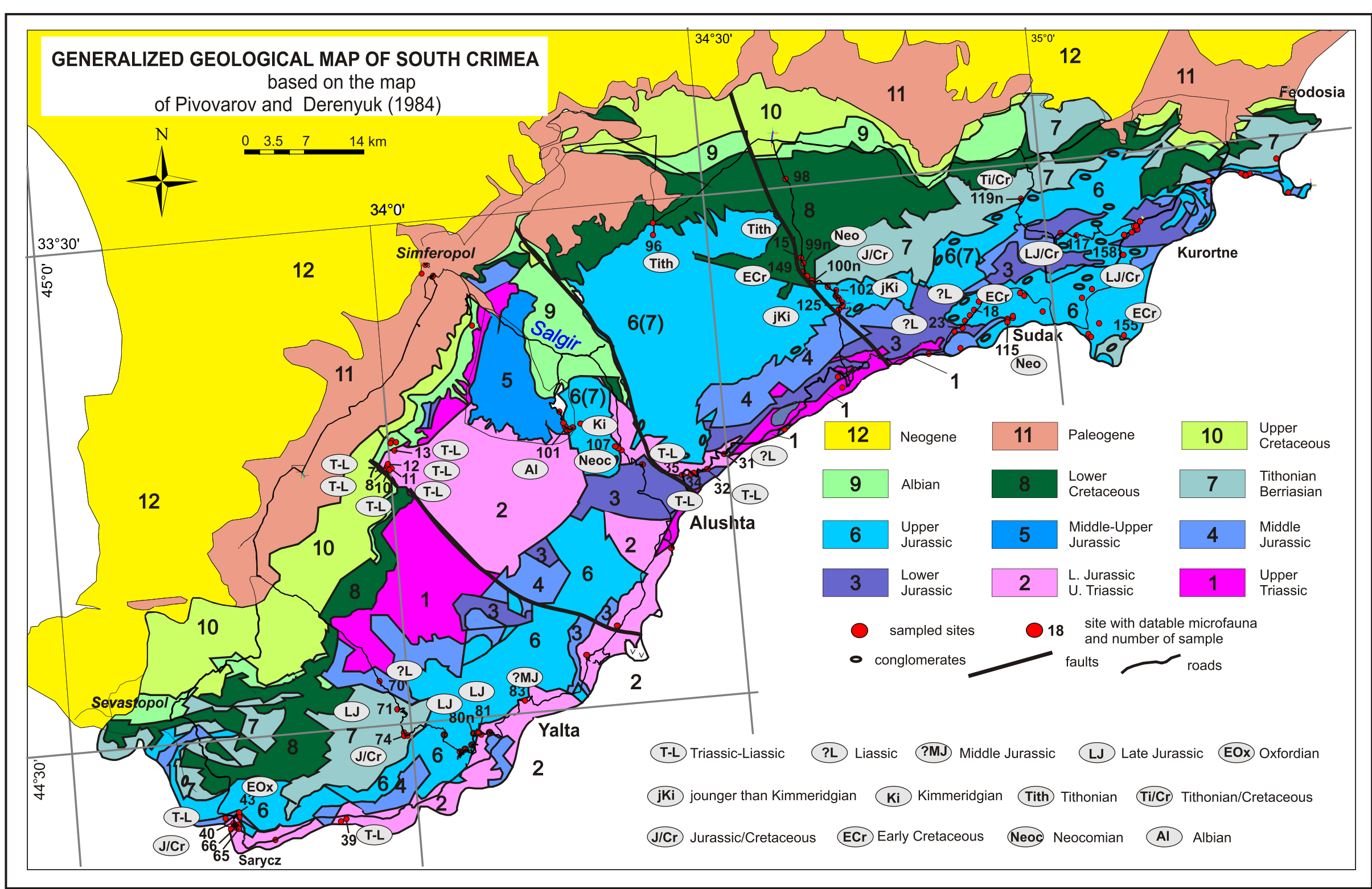

Fig. 4. Simplified geological map of the Crimea Mts. based on Pivovarov and Derenyuk (1984) and Popadyuk et al. (2013a) with location of new dating presented in this paper (see also Appendix 1) 
Iution of the Neo-Tethys (Bocaletti et al., 1974; Letouzey et al., 1977; Adamia et al., 1981; Zonenshain and Le Pichon, 1986).

As far as the polyphase structural evolution of the Crimea is concerned, there is some controversy about the major structures, especially related to the vergence of thrust sheets and the ages of their development. Mileev et al. (1997) considered the thrust sheet development as Berriasian in age with a south and south-east vergence (N160-N120 in azimuth). Popadyuk and Smirnov (1991) assumed that the thrusting in Crimea was generally north-vergent and had occurred during the Austrian phase (Middle Cretaceous). Galkin et al. (1994) concluded that the allochthonous Upper Jurassic rocks of the Chatyr Dagh Massif thrust to the west over the Albian deposits. According to Shcherba (1978), the allochthonous complex (Late Jurassic terranes) was displaced to the south in Late Cretaceous-Early Paleogene times, and the detachment surface was reactivated during the Plio-Quaternary. Kazantsev (1982) and Kazantsev et al. (1989) reported that the structural complexes are involved in north-vergent thrust sheets including rocks aged from the $\mathrm{Pa}$ leozoic to Sarmatian.

Panek et al. (2009) applied an apatite fission-track thermochronology (AFT) to investigate the low-temperature thermal evolution of the CM. The vast majority of the samples taken from Jurassic sedimentary and magmatic rocks revealed AFT ages in the range of 51-32 Ma (Eocene). These studies showed that the mountain range experienced a thermal overprint after the Late Cimmerian orogeny: at least $4 \mathrm{~km}$ of burial by the Early Cretaceous/Late Eocene platform was followed by Middle Pliocene uplift, fluvial erosion and large-scale landslides.

Sheremet et al. (2014, 2016a), based on new micropalaeontological data, proposed Upper Triassic to Middle Jurassic and Lower Early Cretaceous ages of the Tauric Group in the eastern CM, associated with magmatic activity. In this area, they also suggested the Early Cretaceous phase of extension and shortening periods during the Paleocene-Early Eocene, before the main Middle Eocene unconformity. Sheremet et al. (2016b), on the basis of two integrated transects from the eastern CM to the Sorokin Trough (north of the eastern BS; Fig. 2), documented the Early Paleocene to Pliocene shortening phases linked with the Neo-Tethys closure and uplift of the Great Caucasus. This scenario has been supported by Sosson et al. (2016) who reconstructed the palaeogeographic position of the Black Sea Caucasus area from the Tithonian to Early Paleocene.

\section{CURRENT VIEWS ON THE AGE}

\section{OF THE TAURIDA FLYSCH FORMATION}

Distribution of the TFF in the CM is well-illustrated on several general geological maps 1:200,000 (Muratov, 1969; Pivovarov and Derenyuk, 1984; Yudin, 2009), and on serial geological maps 1:200,000: Eupatoria-Sevastopol and Simferopol-Yalta sheets (Bilecki, 2006a, b).

The TFF is traditionally regarded as the oldest sedimentary formation of the CM, exposed in two separate, northern and southern folded belts (Figs. 3 and 4). The northern one, known as the Kacha Uplifted Zone (Kruglov and Tsypko, 1988), is up to $50 \mathrm{~km}$ long and up to $25 \mathrm{~km}$ wide. In this region, the tectonically multiplied thickness of the TFF reaches a few kilometres (e.g., at least $2299 \mathrm{~m}$ in the Kacha 2 borehole, and $4032 \mathrm{~m}$ in the Kacha 4 borehole - see Bilecki, 2006a). In the east, this region adjoins the Late Jurassic carbonate platform of the Dolhorukovska Yayla along the Alushta/Salgir transversal fault (Kruglov and Tsypko, 1988; Fig. 4). Towards the SW, the outcrops of the TFF narrow and disappear under the Lower Creta- ceous transgressive formations in the NW, and under the Middle/Upper Jurassic deposits in the SW and SE (Fig. 4). The southern region of the TFF, which is up to $100 \mathrm{~km}$ long and only a few kilometres wide, is situated along the Black Sea coastal zone, between the Sarych Cape in the west and the Sudak area in the east (Figs. 3 and 4). In the north, the TFF adjoins the Main Ridge of the CM along the vertical walls of the Late Jurassic carbonate platform. The nature of this contact is not clear.

The TFF is divided by Pivovarov and Derenyuk (1984) into the Upper Triassic and Upper Triassic/Lower Jurassic members. In the Lozove and Bodrak areas, these members are separated by thick-bedded quartzitic sandstones with imprints of Sinemurian ammonites and blocks of Paleozoic and Mesozoic limestones (e.g., the Eksi-Orda Fm.; Panov et al., 2001). In the coastal zone between Hurzuf and Alushta, the TFF is intruded by Middle Jurassic volcanic bodies: gabbro-diabases, andesites, basalts, diorites and plagiogranites (Pivovarov and Derenyuk, 1984; Kruglov and Tsypko, 1988; Bilecki, 2006b; Yudin, 2009; Solov'ev and Rogov, 2010; Meijers et al., 2010). In the NW sector of the CM, the TFF is transgressively overlain by Lower Cretaceous, mainly Hauterivian deposits (Figs. 3 and 4). Unclear situation is near the town of Dobre (south of Simferopol), where the TFF is covered by red continental conglomerates regarded by Pivovarov and Derenyuk (1984) as Callovian/Oxfordian, and by Popadyuk et al. (2013) as Neogene? Along the Black Sea coast, between the Cap of Sarych and Pryvitne, a prominent position is occupied by the Tithonian/Berriasian carbonate platform (Fig. 4), up to $2000 \mathrm{~m}$ thick (Krajewski and Olszewska, 2007; Dorotyak, 2008; Krajewski, 2010). This platform is underlain by the Oxfordian and Kimmeridgian conglomerates, sandstones an limestones (Pivovarov and Derenyuk, 1984), and it lies below the Triassic/Jurassic flysch deposits. This sequence is well exposed beneath the Baydar Yalta-Chatyr-Dag and Demerji yaylas (Figs. 3 and 4). A similar relationship between the TFF and the Upper Jurassic/Berriasian limestone sequences continues eastward (Karabi Yayla) as far as the Arpat Creek in Pryvitne. According to Lalomov (2007), the Upper Jurassic Conglomerate Formation (UJCF) unconformably overlies the TFF in this area, and creates a kind of "lenses" at the base of the Upper Jurassic limestones. In this interpretation, the UJCF is tripartite and reaches $750 \mathrm{~m}$ in thickness (e.g., Demerji area). The lower member of this formation (up to $300 \mathrm{~m}$ thick) is composed of boulder/pebble conglomerates with sandy clayey matrix. The middle member, up to $250 \mathrm{~m}$ thick, is represented by medium- to well-rounded boulder/pebble conglomerates with medium-sorted matrix. The upper member of the UJCF, up to $200 \mathrm{~m}$ thick, is dominated by medium/fine-grained sandstones with gravel and small pebbles. In this interpretation, the debris-flow deposits of the UJCF were transported to the basin from the NW. This is confirmed by the granite boulders derived from the Ukrainian Shield (see Lalomov, 2007).

In the Sevastopol area, the uppermost part of the UJCF could be partly correlated with the Hurzuf Formation ( $50 \mathrm{~m}$ thick), composed of algal limestones, sands and conglomerates (Bilecki et al., 2006a). Probably, a similar position is occupied by the Sukhoriche Formation (Oxfordian/Kimmeridgian), composed of conglomerates, sandstones and biohermal limestones, up to $500 \mathrm{~m}$ thick (Bilecki, 2006a).

Along the shoreline, east of the mouth of the Salgir River up to Morskie village the TFF occurs in a narrow zone tapering toward the $E$. In this area, the TFF is locally overlain by patches of the Aalenian/Bajocian gravelithes with coal intercalations (Pivovarov and Derenyuk, 1984). In the Morske village the TFF disappears under a cover of Bathonian/Callovian silty-sandy sediments (Pivovarov and Derenyuk, 1984). 
According to Yudin (2009) the contacts of the TFF with older and younger formations are mainly tectonic and accompanied by wide zones of tectonic mélanges. The TFF is transgressively overlain by Lower Cretaceous deposits only between the Salgir and Bodrak rivers. In the rest of the CM, the contacts of the TFF with both the younger and older formations are tectonic.

Until recently, the Late Triassic/Early Jurassic age of the TFF was relatively poorly documented by biostratigraphic, lithostratigraphic and sedimentological studies. The stratigraphic position of the TFF is based on few findings of ammonites (Astakhova, 1968a, b, 1971, 1972, 1976), crinoids, the Upper Triassic bivalve Monotis salinata (Klikushyn, 1988; Okay et al., 2015), and palynological data (Bolotov et al., 2004 and references therein). However, when we critically analyse these dates, we should take into account the fact that turbidite sediments contain usually reworked fossils and palynological material (e.g., Oszczypko et al., 2004, 2012a). Reworking proceses during the deposition of the TFF are confirmed by the presence of numerous blocks of both sedimentary rocks with fossils, and plutonic and volcanic rocks (Muratov, 1960; Albov, 1964; Ippolitov et al., 2008; Yudin, 2009). Popadyuk (2011) referred to a forgotten publication of Dekhtyareva et al. (1978) where, in addition to the Carboniferous, Permian, Triassic to Middle Jurassic, and Upper Triassic to Lower Jurassic fossils in the exotic blocks of the Eksi-Orda Formation near Simferopol, also the Barremian-Aptian ammonites have been found. Taking into account these data, Popadyuk (2011) questioned the Aptian-Albian age of the TFF, while the age of the post-tectonic sedimentary cover of the $\mathrm{CM}$ should be not older than Cenomanian.

Taking into account the interdependence of volcanism and sedimentation of the TFF (see Kruglov and Tsypko, 1988), the studies of detrital zircons from outcrops located near Simferopol and along the Black Sea coast between Yalta and Alushta as well as from the Kastel Massif (west of Alushta) supplied important information (Solov'ev and Rogov, 2010). They provide the following dates (in Ma): $220.1 \pm 12$ and $169.9 \pm 8.6$ in the north, $193.6 \pm 13.1,167.1 \pm 12.1$ and $154.0 \pm 10.2$ on the seashore, and $149.0 \pm 10.9$ in the Kastel Massif, thus showing that the age of detrital zircon corresponding to the interval between the Late Triassic to Middle Jurassic and the Oxfordian/Kimmeridgian (Late Jurassic) is similar to the usually accepted age of the TFF, and suggests synchrony of volcanism (Late Triassic-Middle/Late Jurassic) and flysch sedimentation.

Meijers et al. (2010) documented the presence of two groups of volcanic rocks in the Crimea Mts.: older - Aalenian to Oxfordian ( 172-158 Ma in the area of the Bodrak Valley and near Simferopol) and younger - Tithonian-Berriasian ( 151-142 Ma in Karadag).

The preliminary results of our geological and micropalaeontological studies (Oszczypko et al., 2012b, c) on the TFF in the Bodrak area and along the Black Sea coast confirmed its Upper Triassic-Middle Jurassic age in these localities. They also documented that the Middle/Upper Jurassic Flysch is trangressively overlain by the Upper Oxfordian/Kimmeridgian marine deposits near Laspi. Popadyuk et al. (2013) published a new geological map of the CM $(1: 200,000)$ based on determination of 51 foraminifer species and revision of 163 sections (Fig. 3), and pointed out the Aptian/Albian age in the western part of the CM.

The other area of occurrence of the Aptian/Albian deposits is in the eastern part of the CM between Sudak and Feodosia. Unfortunately, in places of typical occurrence of the TFF, samples were barren.

Recently, Sheremet et al. (2014) published important papers concerning large-scale studies of of calcareous nanno- plankton. In course of their project, they collected 224 samples, of which only 52 allowed concluding about their age. These positive samples have been picked up from marly shales, limestones, flysch and flysch-like deposits of the eastern sector of the CM, between Simferopol in the west and Feodosia in the east. The ages of these deposits are not younger than Valanginian in the east and Aptian/Albian in the west. In turn, in the western sector of the CM (W of the Salgir Valley), and along the coastal area between Alushta and Morske, where the TFF is dominant, all samples were empty. However, these results have not been correlated with any lithostratigraphic units shown in geological maps (Pivovarov and Derenyuk, 1984; Bilecki, 2006a, b; Yudin, 2009) and, moreover, samples collected from the unquestionable TFF deposits have been usually barren. In another publication, Sheremet et al. (2016a) give additional micropalaeontological data (e.g., from Berehove and Yalta) and provide a new interpretation of the structural evolution of the $\mathrm{CM}$ (Fig. 3).

\section{METHODS}

For our studies, we used the geological map 1:200,000 (Pivovarov and Derenyuk, 1984), edited by the Ukrainian Geological Survey. This map well-illustrates the main lithostratigraphic units of the CM (Fig. 4) and shows that the Upper Triassic-Lower Jurassic flysch deposits of the TFF are distributed in two areas: west of the Salgir River (Kacha Uplift) and along the sea shore, between the Sarych Cape in the west and the village of Morske in the east (Figs. 3 and 4).

Initially (2011-2012), our interest was focused on lithostratigraphical studies and sampling of the TFF in its locus typicus area, located west of the Salgir River (Fig. 4) and along the Black Sea coast, between the Sarych Cape in the west and the village of Pryvitne in the east (Oszczypko et al., 2012b, c). Later (2013), these studies were extended on the Jurassic/Lower Cretaceous flysch of the eastern sector of the CM. Our research was carried out along the main road and six selected localities. The studied and sampled sections were documented by GPS way-points (WP) and photographs. During fieldwork, we collected 98 samples for biostratigraphic study, of which 48 samples appeared barren. In the remaining sections (50 samples collected from 37 sites; Figs. 3 and 4) the age determination was based on microfossils (foraminifera and calcareous nannoplankton). Microfacies types have also been determined. In the laboratory, standard processing methods were applied to isolate the foraminifera and dinocysts from shales and mudstones. In general, the samples from shales and mudstones of the TFF contained scarce foraminifera and dinocysts. Additionally, both microfacies and calcareous nannoplankton were analysed in thin-sections from several limestone samples.

\section{STUDIED SECTIONS}

\section{WESTERN SECTOR OF THE CM}

Our research focused on stratotype areas of the TFF near Prokhladne, south of Simferopol, and along the coast from Rybache in the east to the Sarych Cape in the west (Figs. 3 and 4). 


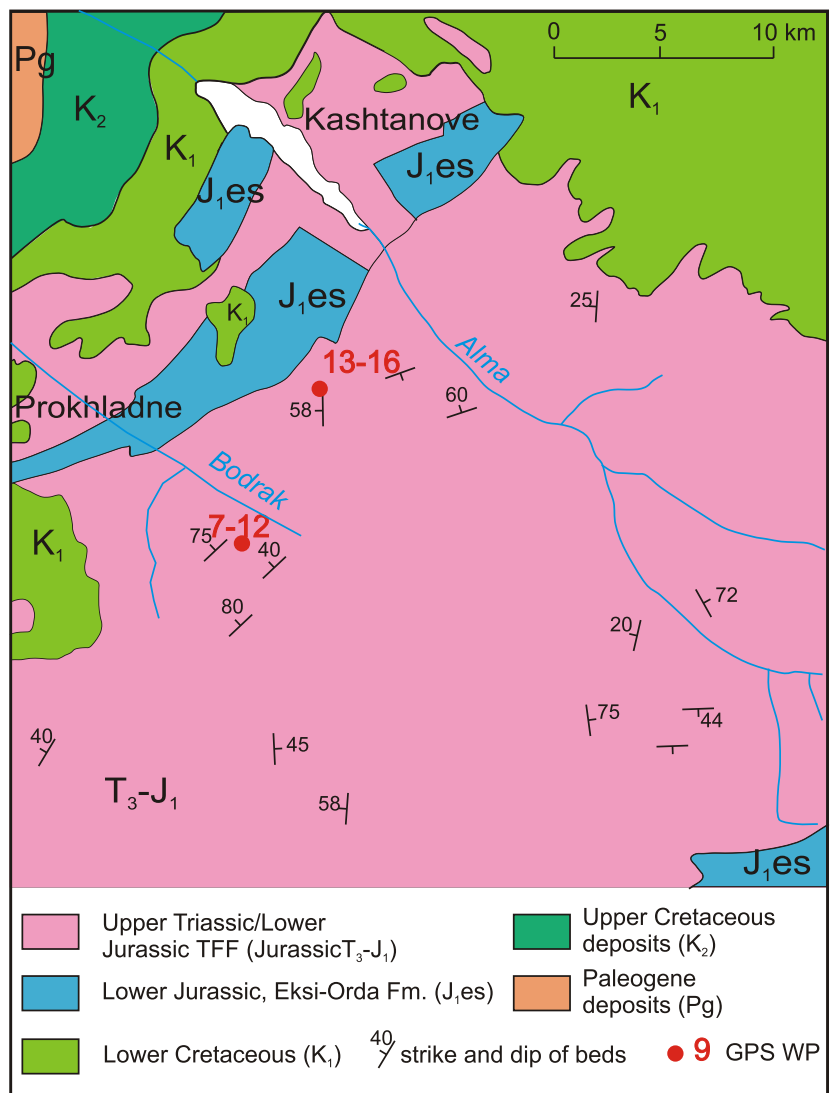

Fig. 5. Geological sketch-map of the Prokhladne area, based on Bilecki (2006b)

Prokhladne area. This area of good outcrops, located on hills between the rivers of Bodrak and Alma (Figs. 5 and 6A-E), is regarded as locus typicus of the Taurida Flysch Formation of Upper Triassic-Lower Jurassic age (e.g., Muratov, 1960; Levitskiy, 1974; Marcinowski and Najdin, 1976; Muratov et al., 1984; Baraboshkin, 1997). In Prokhladne, remains of ammonites (Dactilioceras sp.) and belemnites (Mesoteuthis quenstetdti) were found at the top of the TFF, which point to the Toarcian/Aalenianian age of this formation (Levitskiy, 1974). In the same position, directly below Hauterivian transgresive deposits, Levitskiy (1974) documented the presence of Palaepolycheles crymensis. Modern representatives of this family belong to the marine benthos, occurring at depths of up to $2000 \mathrm{~m}$.

Cartographic position of the TFF in this area is presented on geological maps of Pivovarov and Derenyuk (1984), Bileck (2006a, b) and Yudin (2009). The first group of exposures (WP 7-12) displays dark grey non-calcareous, fine to very fine, thinto medium-bedded turbiditic sandstones with shaly and mudstone intercalations, sideritic concretions and rare thick sandstone beds (Fig. 6A-D). Few flute casts of medium-bedded turbiditic sandstone indicate palaeotransport from NW to SE $\left(300^{\circ}\right)$. Greenish-brown shales are covered with reddish/black patina of Fe/Mn minerals (Fig. 6C, E). Subvertically dipping beds are folded and many of them are overturned. Some packages of strongly tectonized beds can be regarded as a kind of "broken formation" (Fig. 6F). About $1.8 \mathrm{~km}$ to the north (WP 14, 15; Fig. 5) we found steeply NW-dipping (340/60) thin-bedded turbidites with two diabase sills $(0.5$ and $4 \mathrm{~m}$ thick, see Meijers et al., 2010) showing thermal contacts (Fig. 6D). There is a narrow, up to $1 \mathrm{~km}$ wide, NE-SW-oriented syncline of the Eksi-Orda Beds (Lower Jurassic) between the Alma and
Bodrak valleys. Both the TFF and Eksi-Orda Beds are locally transgressively overlain by lobes of Lower Cretaceous deposits, mainly of Albian age (Marcinowski and Najdin, 1976). Bolotov et al. (2004), based on palynofossils and the Norian bivalve Monotis sp., documented the Toarcian-Aalenian age of the TFF in the Bodrak River sections. Thin-bedded flysch, similar to that described above, we have observed and sampled also in several exposures along the Black Sea coast, between Rybache in the east and Alushta and the Laspi Bay in the west.

In the poor foraminifera assemblage identified in WP 7, 8, 10-13 (Fig. 5), one species, Thuramminoides metensis (Terquem) (Fig. 7), is characteristic for the Middle Triassic, and another one, Thalmannammina canningensis Tappan, is also reported from the Triassic-Lower Jurassic. Preliminary studies of organic dinocysts from the Bodrak section (WP 7-17) indicated poorly preserved Lower Jurassic dinocysts: Phallocysta sp., Wallodinium and Nannoceratopsis sp. Nannoceratiopsis senex and $N$. gracilis have been occasionally observed, indicating a Late Pliensbachian-Early Bajocian age (Oszczypko et al., 2012c).

Laspi area (Figs. 8, 9 and 10). To the west of Yalta (Figs. 3 and 4), along the coastline, and near Laspi we observed well-exposed flysch. On the geological map of Bilecki (2006a; Fig. 8) these flysch deposits have been included into the upper part the Taurida Formation $\left(\mathrm{T}_{3}-\mathrm{J}_{1}\right)$ and the Aalenian/Bajocian flysch $\left(\mathrm{J}_{2} \mathrm{ml}\right)$ with tuffite intercalations and small subvolcanic diabase veins of Middle Jurassic age. In comparison with the flysch of the Prokhladne sections, turbidites of this area differ in colour and show less intense tectonisation of beds. West of Yalta, in Berehove along the Black Sea coast, we found well-exposed flysch deposits (WP 39; Fig. 8). Previously, these deposits were regarded by Pivovarov and Derenyuk (1984) and Yudin (2009) as the TFF $\left(T_{3}-J_{1}\right)$. These outcrops display $\mathrm{N}$-dipping (360/35) dark grey thin- to medium-bedded turbidites with thickening- and coarsening-upward sequences (Fig. 9A-C). In general, the flysch deposits from Berehove are significantly different from that of the Bodrak Valley and coastal zones east of Alushta, in both the colour and degree of tectonic deformation of beds.

In the Berehove section (WP 39), a relatively rich Early Jurassic foraminiferal assemblage has been identified in grey siltstones (Figs. 8 and 9A-C, 10; Appendix 1). A thin-section of the same sample also reveals the presence of Upper Jurassic foraminifera. Additionally, from the same locality (Berehove/Kastropol, sample 40 located at $225 \mathrm{~m}$, azimuth 75 from WP 39), Sheremet et al. (2016a) reported the presence of Hauterivian-Early Barremian calcareous nannoplankton. Early Cretaceous (Upper Valanginian-Lower Barremian) calcareous nannoplankton has also been documented in a sample from Yalta (Sheremet et al., 2016a:, sample 42).

Going to the west along the road $\mathrm{H}-19$ to the locality of Laspi, we observed and sampled the shaly facies probably belonging to the upper part of the TFF (WP 40; Appendix 1). In the dark beige mudstones, a relatively rich Upper Triassic- Lower/Middle Jurassic foraminiferal assemblage has been documented.

To the NW of the Sarych Cape, above the road $\mathrm{H}-19$, the upper shaly facies of the TFF (WP 40) are transgressively overlain by poorly cemented fine gravel, $10-15$ m thick, with claystone (WP 42, 43; Fig. 8). These Upper Jurassic clayey-sandy deposits, with clasts of rhodoid limestones, up to $5 \mathrm{~cm}$ across, contain (WP 43) a relatively rich foraminiferal assemblage (Appendix 1) accompanied by ostracods, echinoids, spikes and calcified radiolarians. Its likely age is Early/Middle Oxfordian. A thin-section (WP 43, thin-section 1) revealed the presence of microbial bindstone containing few foraminifera: Textularia sp., Bullopora sp., Nubeculariidae, accompanied by Polychaeta - 

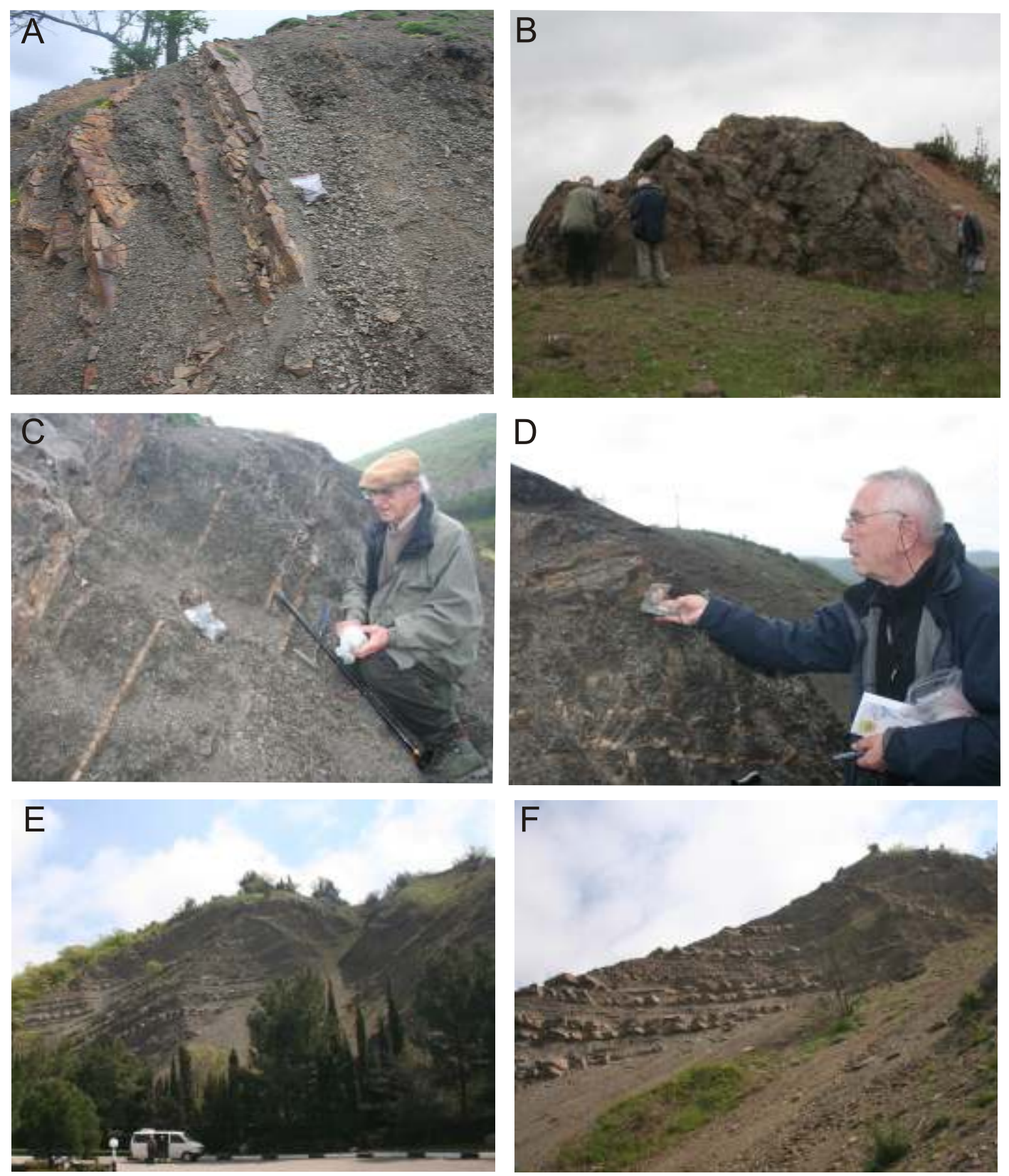

Fig. 6. Taurida Flysch Formation of the Bodrak Valley

A - thin-bedded turbidites dominated by dark grey non-calcareous shales and mudstones with rare intercalations of thin-bedded sandstones, with rust-coloured weathering crust (sample WP 7); B - sill of Middle Jurassic volcanites; C - shaly lithofacies of TFF with few centimetres thick intercalations of very fine sandstones (WP 8); D - strongly tectonized shaly lithfacies of TFF (WP 9); E - coarsening- and thickening-upward sequence, upper part of TFF; $\mathbf{F}$ - details of above photographed sequence

Terebella lapilloides Munster, and local accumulations of sponge spicules. This assemblage points to Late Jurassic age. Similarly, a thin-section (WP 43, thin-section 2) from micritic limestone contained poor, but stratigraphically important microfossils (Appendix 1). The age corresponds to late Early-Middle Oxfordian.

In 2012, along the road to Laspi, above samples WP 42-43, samples from the Late Jurassic carbonate platform of the Baydarska (e.g., WP 65; Appendix 1) were collected. These sample contains abundant microfossils indicating Late Jurassic to Early Cretaceous age. The limestones exposed along the road from Laspi to Sokolyne (sample WP 71) contain calcare- ous nannoplankton (Nannoconus steinmannii) indicating Late Jurassic-Early Cretaceous age. Sample WP 74 has also yielded a calcareous nannoplankton assemblage with Cyclagelosphaera argoensis and C. margerelli Noel, which indicates Late Jurassic to Early Cretaceous age (Appendix 1).

Chatyr-Dag Yayla (Figs. 11 and 12). In the Salgir River Valley, near Dobre (a few kilometres south of Simferopol), we turned off the main road and continued moving up the local road towards the Chatyr-Dag Massif (1527 m a.s.I.). In the roadside exposures, red thick-bedded conglomerates with the red sandy-clayey matrix occur. These NW-dipping continental deposits stretch along the road for a few hundred metres (Fig. 

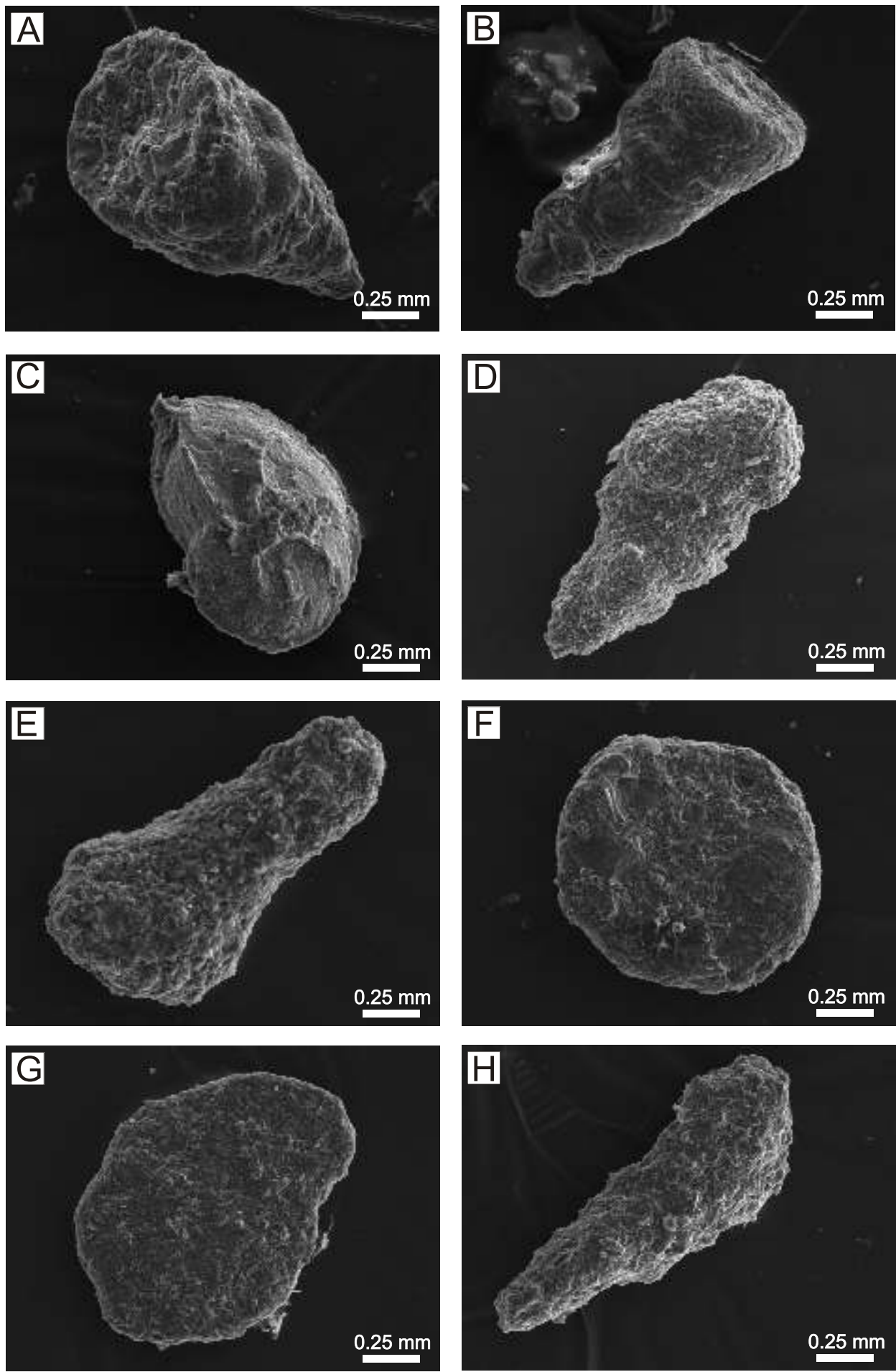

Fig. 7. Microphotographs of foraminifers from TFF (Late Triassic-Early Jurassic), obtained by water maceration

A - Kechenotiske cf. maurikensis Haig and Mc Cartain, WP 39, side view; B - Palustrella exigua (Schwager), WP 18, side view; C - Astacolus cf. varians (Bornemann), WP 40, side view; D Textularia aff. haeusleri Kaptarenko Chernousova WP 18"2011", side view; E - Ammobaculites cf. rhaeticus Kristan-Tollmann, WP 23, side view; $\mathbf{F}$ - Thuramminoides metensis (Terquem), WP 8, side view; G - Trochammina sp., WP 39, apertual view; H - Verneuilinoides cf. liasina (Terquem and Berthelin), WP 39, side view 


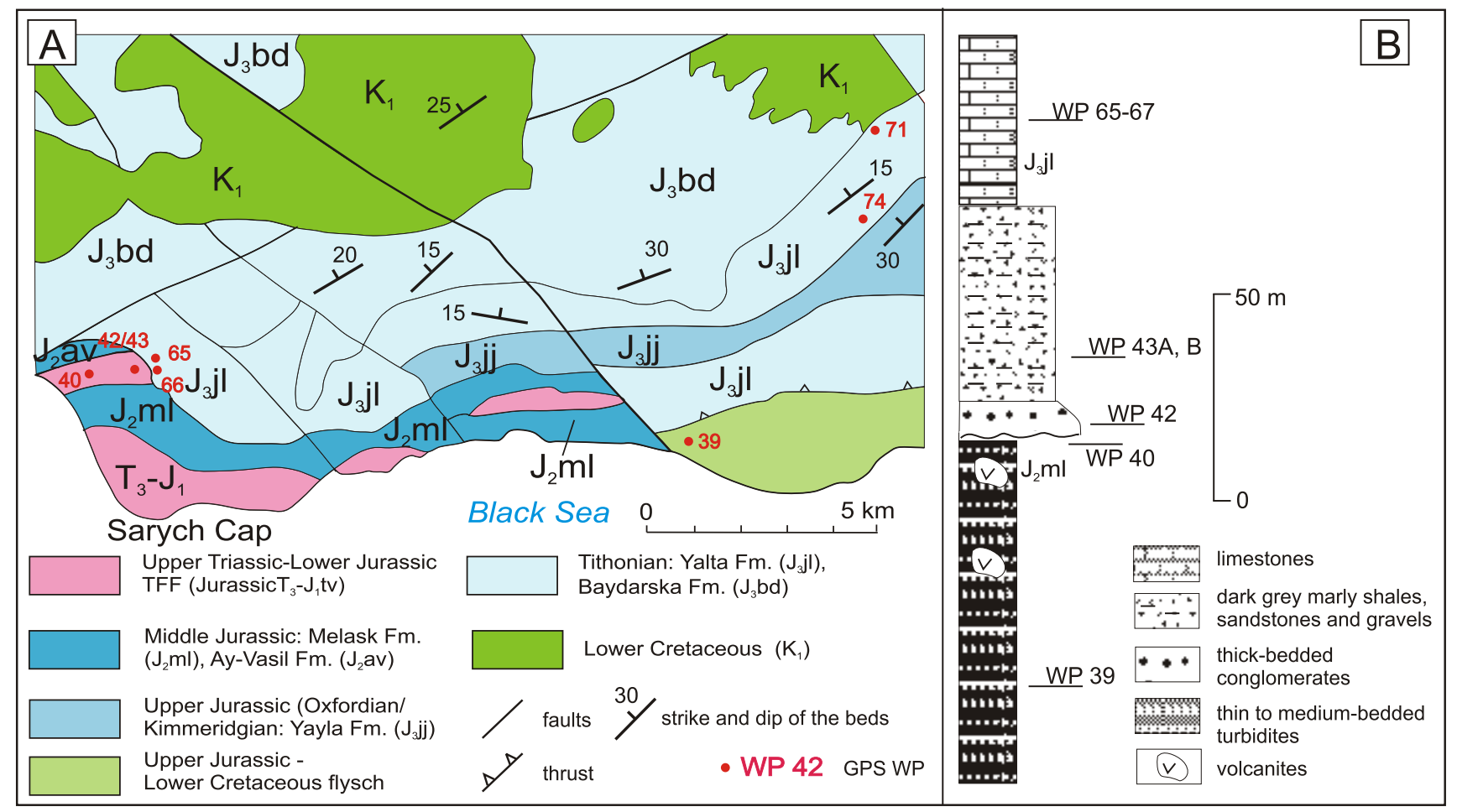

Fig. 8A - geological sketch-map of the Laspi area, based on Bilecki (2006a), with location of sampled sections; B - simplified lithostratigraphic profile with location of sampled sites
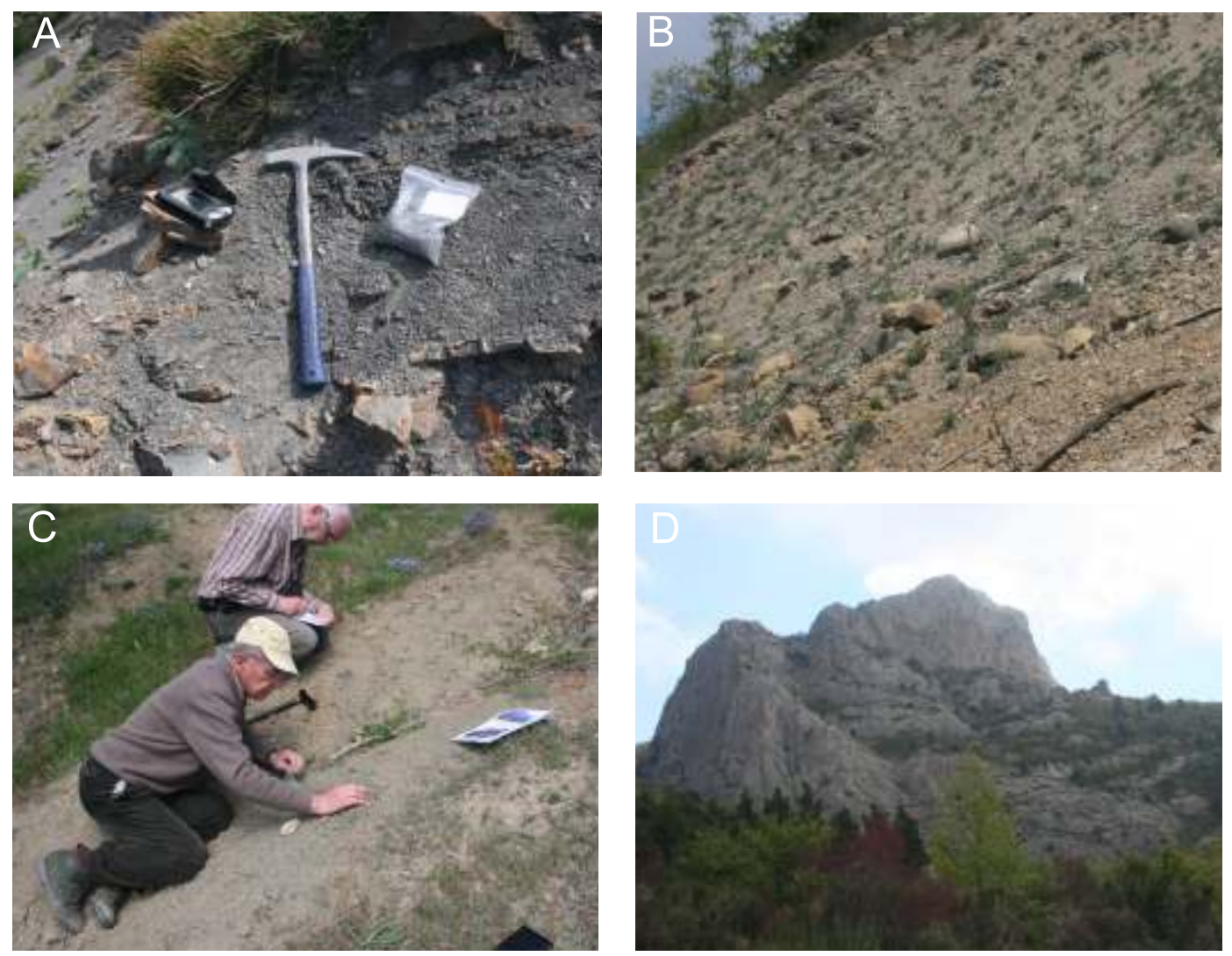

Fig. 9. Relationship of TFF to the Late Jurassic carbonate platfom of Baydarska Yayla near Laspi

A - locations of samples WP 38/39; B - WP 42/43, poorly cemented, coarse-grained sandstones, conglomerates and limestone concretions in sandy matrix of the Upper Oxfordian/Kimmeridgian, at the base of hard limestones (Tithonian/Berriassian, see Oszczypko et al., 2012b, c); C - fine gravels and sands (sample WP 42); D Tithonian/Berriasian limestone 

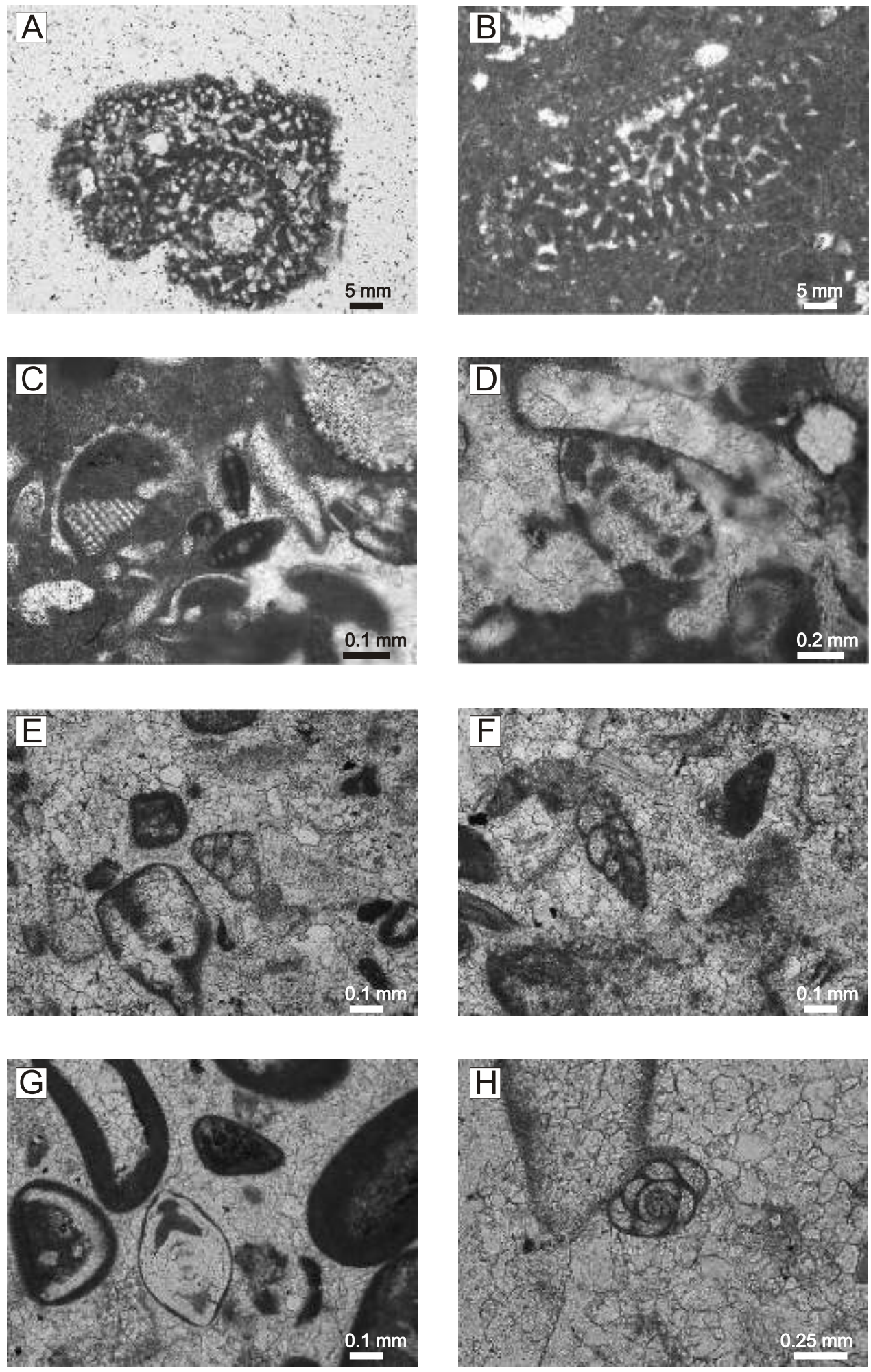

Fig. 10. Foraminifers of the Crimea Mts. found in thin-sections

A - Anchispirocyclina lusitanica (Egger), S.6/WP 71, equatorial cross-section, Late Jurassic (Tithonian); B - Anchispirocyclina lusitanica (Egger), S.6/WP 71, oblique cross-section, Late Jurassic (Tithonian); C - "Vidalina" martana Farinacci, WP 70a, equatorial and oblique cross-section, Lias; D Involutina cf. liasica (Jones), WP 70a, axial cross-section, Early Jurassic; E - Pseudomarssonella osoviensis (Bielecka and Styk), WP 70a, axial cross-section, Middle Jurassic; F - Siphovalvulina variabilis Septfontaine, WP 70a, axial cross-section cutting, Middle Jurassic; G - Protopeneroplis striata Weynschenk WP 70a, cut crosswise, axial cross-section, Middle Jurassic; Sudak-Feodosia transect; H - Quinqueloculina cf. occulta Antonova, WP 70a, cut crosswise, axial cross-section, Middle Jurassic; Sudak-Feodosia transect 


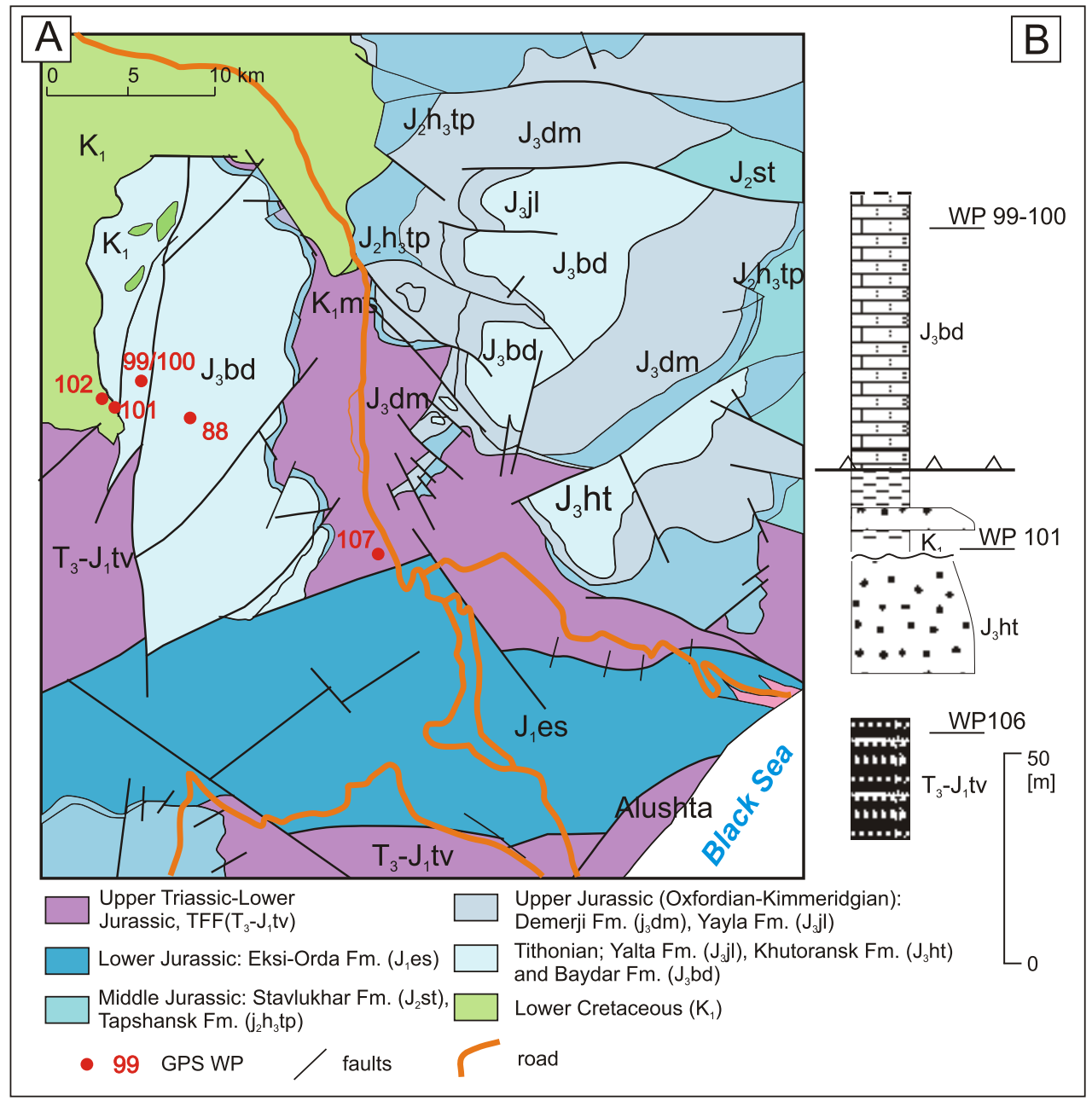

Fig. 11A - geological sketch-map of the Chatyr-Dag-Alushta area, based on Bilecki (2006b), with location of sampled sections; B - simplified lithostratigraphic profile with location of sampled sites

11A). The conglomerates have been included by Pivovarov and Derenyuk (1984) into the Callovian/Oxfordian, by Yudin (2009) into the Lower Cretaceous, and by Popadyuk et al. (2013) into the Neogene. Going up to the east, on a steep hillside, the variegated conglomerates are followed by thick beds of Oxfordian grey conglomerates (Fig. 12C). These conglomerates are overlain by highly tectonized dark grey marly shales that contain mainly pyritized microfossil pseudomorphs, not older than Albian (WP 101; Appendix 1). The Albian shales are overthrust by the Tithonian/Berriasian grey limestones (Fig. $12)$, steeply dipping to the east (85/51). Higher up, along the road to Mramorna Pechera (WP 99/100 and WP 88), karstified limestones of the Chatyr-Dag carbonate platform are exposed. These limestones contain Tithonian-Berriasian microfossils (Appendix 1). It needs to be highlighted that marly shales from WP 101 clearly correlate with the Albian $\left(\mathrm{K}_{1}\right.$ al1-2) clays with fossils and siderites (Pivovarov and Derenyuk, 1984). These deposits are exposed also in the Salgir River Valley on the western margin of the Demerji Yayla carbonate platform. A few kilometres to the SE in the valley separating Demerji and Chatyr-Dag yaylas, at the petrol station (WP 107; Figs. 11 and $12 \mathrm{E})$ in a cross-cut of a road, we found the south-dipping (190/40) dark grey thin-bedded flysch classified by Pivovarov and Derenyuk (1984) as the upper part of the TFF $\left(T_{3}-J_{1}\right)$. However, we found relatively abundant microfossils, ostracods and spines of sea urchins in sample WP 107 (Figs. 11 and 12E), clearly indicating Early Cretaceous (Neocomian) age. In a thin-section, foraminifera not older than Kimmeridgian were also observed. Similar flysch occurs near WP 108. In this case, the beds (dipping at 310/30) are exposed in a morphological depression located between the Chatyr-Dag (1527 m a.s.I.) and Demerji (1350 m a.s.l.; Fig. 12F) limestone massifs. This situation gives an impression that these flysch strata dip beneath the carbonate platforms (cf. Popadyuk and Smirnov, 1991). An interesting result was provided by sample WP 80 collected close to Yalta from grey calcareous mudstones. These deposits were regarded by Pivovarov and Derenyuk (1984) as the uppermost part of the Tauride Flysch $\left(T_{3}-J_{1}\right)$ located beneath the carbonate platform. Sample WP 80 contains calcareous nannoplankton (Appendix 1), including Watznaueria barnesae (Black) Perch-Nielsen, which could be interpreted as not older than Middle Jurassic and not younger than Early Cretaceous.

Results of sampling along the road cross-sections. In addition to the previously described exposures, our research covered also the outcrops located along the roads in the western part of the CM (Figs. 3 and 4). In these areas, we recognized, among others, the Upper Jurassic/Lower Cretaceous microfacies (WP 71, 80, 81) typical of the carbonate platform (Appendix 1) NE of Yalta. In the Alushta region, we have acquired data on the Upper Triassic/Lower Jurassic TFF (WP 31, 

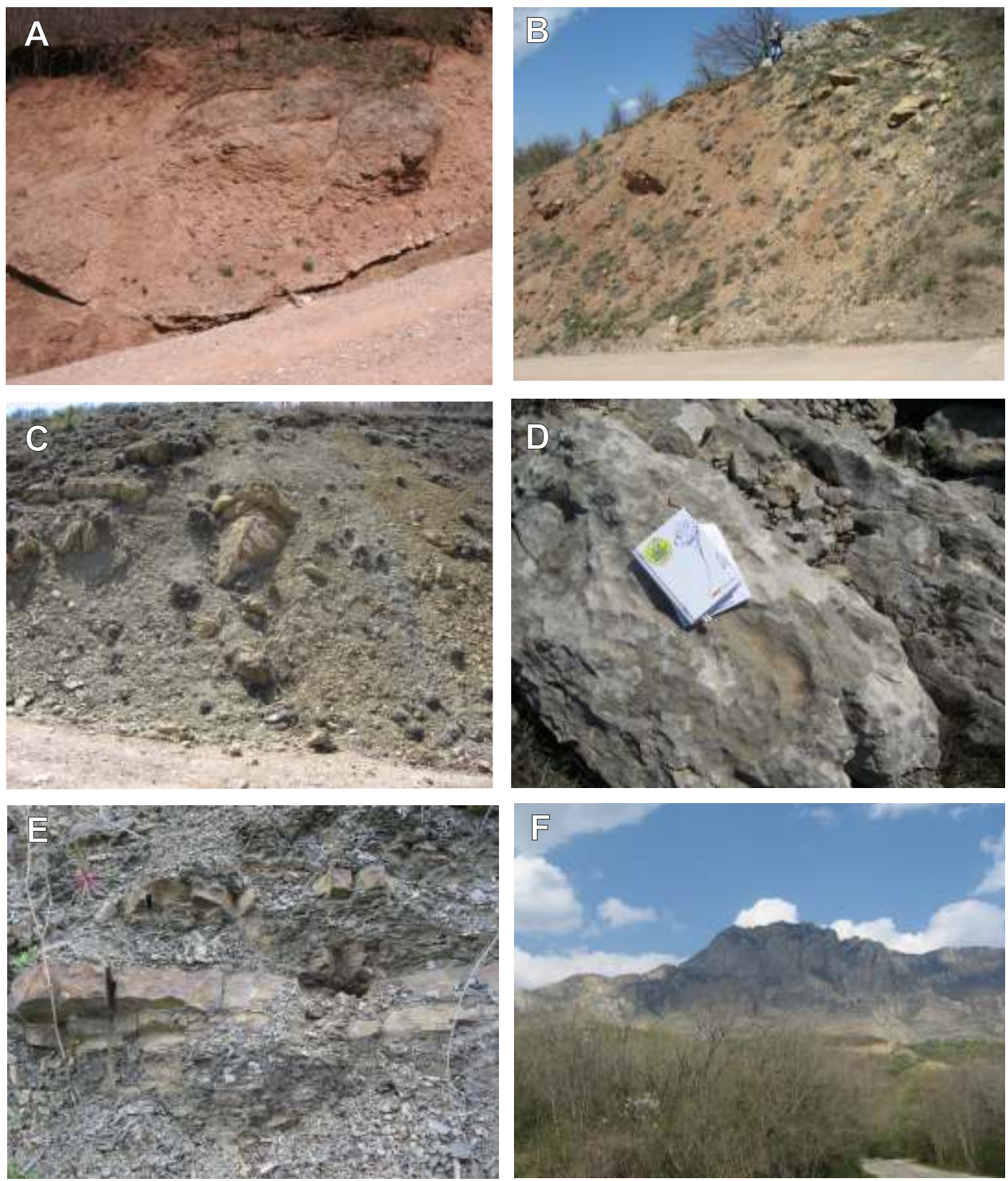

Fig. 12. Relation of the Late Jurassic carbonate platform (Chatyr-dag Yayla) to its sedimentary basement

A - red continental conglomerates of TFF (Middle Jurassic?), WP 106; B - Oxfordian/Kimmeridgian? reddish and grey conglomerates, WP 105; C - breccia of the Aptian dark grey marly shales with blocks of Oxfordian/Kimmeridgian(?) conglomerates; D - Tithonian/Berriasian limestones of Chatyr-Dag Yayla, WP 99; E Lower Cretaceous turbidites regarded as the Upper Triassic/Lower Jurassic deposits of TFF, Demerji Stream, near a petrol station, WP 107; F - Late Jurassic carbonate platform of Demerji Yayla - view from the west

$32,34,35)$, located below the carbonate platform of the Demerji Yayla, and on the northern margin of the Dolhorukovska Yayla.

Eastern sector of the CM. Between the Sudak Bay and the Meganom Peninsula, along the shoreline and directly to the north, N-dipping, dark grey, thin- to medium-bedded turbidites are well-exposed (Figs. 3, 4 and 13). Towards the north, near Solnechna Dolyna, a range of hills exposes thin- to thick-bedded turbidites (Fig. 13D) overlain by conglomerates (Fig. 13E). The folded thick-bedded turbidites are also exposed near Feodosia (Fig. 13F). Further to the east, near Ordzhonikidze, the steep marine cliffs reveal a thick series of Lower Creta- ceous (Hauterivian, see Sheremet et al., 2016a: point 43) thin-bedded flysch. In WP 170, we have documented a $4 \mathrm{~m}$ thick basalt sill that concordantly intercalated flysch deposits. In the Sudak area, we found Upper Jurassic/Lower Cretaceous foraminifera (in WP 153; Appendix 1) and the Upper Jurassic/Lower Cretaceous bioclastic grainstone near Kurortne (WP 158; Appendix 1). The foraminifera determinations confirm stratigraphic data of Sheremet et al. (2014) and Popadyuk et al. (2013). The thin-bedded flysch passes upwards into thick-bedded turbidites and debris-flow conglomerates with huge blocks of Upper Jurassic reef limestones, up to $2 \mathrm{~km}$ across (e.g., 

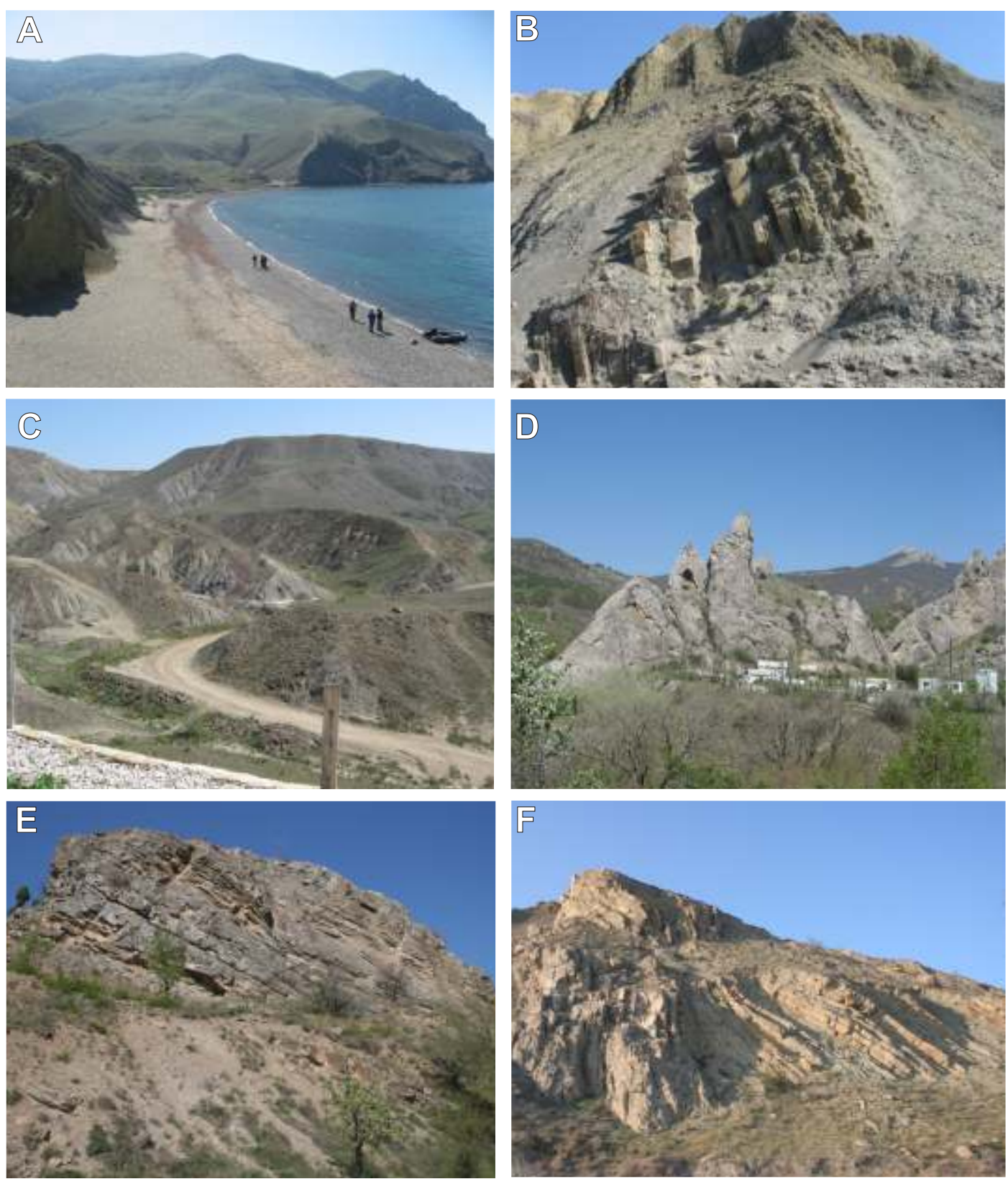

Fig. 13. Lithostratigraphic and sedimentary development of the Sudak Flysch Formation and overlying thick-bedded turbidites and conglomerates

A - Black Sea shore east of Sudak, composed of the Upper Jurassic/Lower Cretaceous flysch formations, view towards the Meganon Peninsula; B - steeply dipping medium- and thick- bedded flysch deposits; C - huge exposures of the Jurassic/Cretaceous flysch, view towards the NE; $\mathbf{D}$ - large conglomerate and sandstone exposures north of Solnechna Dolyna; $\mathbf{E}$ - a packet of thin-bedded flysch overlain by thick-bedded sandstones and conglomerates; example of a thinning- and fining-upward turbidite sequence; $\mathbf{F}$ - thick- and medium-bedded turbidites near Feodosia

Khart-Kaya; see Yudin, 2009). These deposits are exposed between Pryvitne in the west and the Cap Kuuk-Atlama in the east, over a distance of at least $70 \mathrm{~km}$. The width of the outcrops of these beds ranges between $2 \mathrm{~km}$ near Pryvitne to $\sim 30 \mathrm{~km}$ at the Meganom meridian. These coarse clastic cone, underlain by distal turbidites in the south, is overlain by Lower Cretaceous marls and limestones in the north.

The age of this formation is Lower Cretaceous, not younger than Valanginian (Sheremet et al., 2016a).
Morske-Vesele-Novyi Svit sections (Figs. 14-17). These sections are located along the road P 29 from Morske to Sudak (Figs. 3 and 4). The Vesele section begins with the strongly folded flysch of Lower Jurassic (Pivovarov and Derenyuk, 1984) or Middle Jurassic (Bilecki, 2006b) age. These flysch deposits are well-exposed in the right side (S) of the road cross-cut (Figs. 14 and 16). They are represented by series of dark shales and micaceous mudstones with intercalations of NW-dipping, thin- to medium-bedded turbiditic sandstones which display palaeotransport from the $E$ (Fig. 16A-C). These deposits probably ex- 


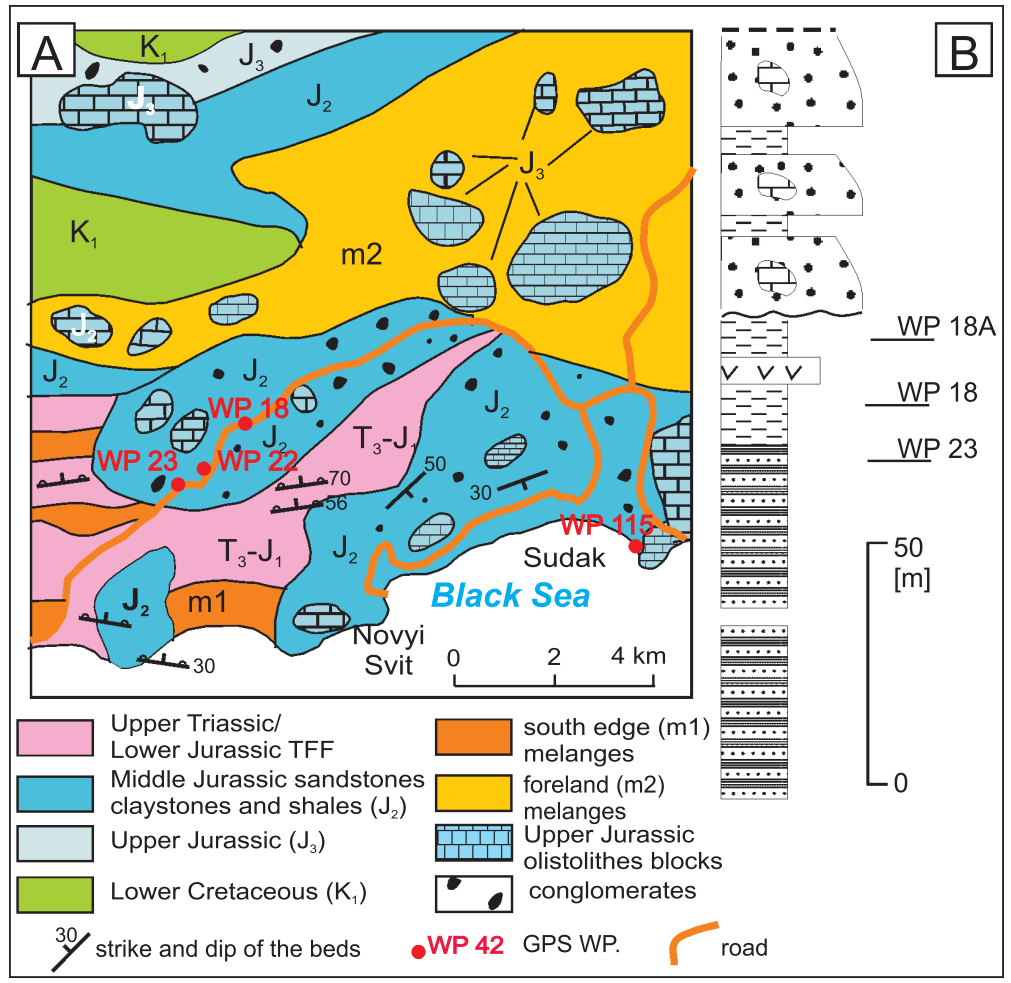

Fig. 14A - geological sketch-map of the Vesele and Novyi Svit area (based on Yudin, 2009) with location of the studied and sampled sections; B - simplified lithostratigraphic section with location of sampled sites fossils come from redeposited material, their precise age cannot be determined.

North of Vesele, in the pass near the crossroads towards Sudak (Fig. 13; WP 18), there is a large block $(5 \times 3 \mathrm{~m})$ of volcanites (Fig. 15F). This is a kind of Middle Jurassic or Upper Jurassic/Lower Cretaceous volcanic sill as a monadnock or olistolith block derived from the Upper Jurassic conglomerates. This block is underlain and overlain by dark grey mudstones which contain Upper Triassic/Lower Jurassic foraminifera at the base - WP 18 (Appendix 1) - and Upper Jurassic microfacies and calcareous nannoplankton at the top - WP 18A (Appendix 1). From the Vesele sections, Sheremet et al. (2014, 2016a) reported the Lower Cretaceous nannoplankton, not younger than Valanginian, collected from marly shales (points Nos. 59-61) located 50-60 m east (azimuth 81) of WP 18A.

In the Vesele section, along the northern side of the road, there are well-exposed different types of conglomerates and thick-bedded turbidites (Fig. 15A, B), matrix-supported debris flows (Fig. 15C), and chaotically organized conglomerates (Fig. 15D). In this section, we recognized deposits of different ages: both Upper Triassic-Lower Jurassic and Upper Jurassic/Lower Cretaceous (WP 23, WP 18 and 18A). There is similar situation with section WP 39 (Berehove). This documented that during the Late Jurassic/Early Cretaceous deposition the Late Jurassic/Early Cretaceous debris flows and turbiditic currents eroded

tend southwards to the Perchem-Kaya (576 m a.s.I.) with very thick, NW-dipping flysch series (Fig. 16D).

The sample collected in WP 22 (Fig. 14) was barren. Further to the west, within grey and beige micaceous mudstones exposed along the $\mathrm{N}$ side of the road, one of the samples (Fig. 13E; WP 23) contained foraminifera that suggest Late Triassic-Early Jurassic age (see Appendix 1). A few hundred metres further to the east, these flysch deposits are overlain by a thick conglomerate complex exposed on the left $(\mathrm{N})$ side of the road (Fig. 15E) and dipping towards the NE. The age of these conglomerates has been differently interpreted: as Upper Callovian-Early Oxfordian by Pivovarov and Derenyuk (1984) and Bilecki (2006b) and as Middle Jurassic sandstones, mudstones and argilites with the Upper Jurassic reef limestone olistolith by Yudin (2009).

According to our observations, these deposits consist of thick-bedded, graded, channelized conglomerates, pebbly mudstones, and sedimentary breccias. They contain pebbles and large blocks of limestones with macrofossils and fragments of brachiopods. This coarse-grained complex shows a thinning-upward sequence with more sandstone intercalations upper in the section. The exact characteristics of the thick-bedded turbidites and debris-flow conglomerates with limestone blocks is shown in Figure 14B.

The conglomerates are composed of variously sized Upper Jurassic limestone blocks and boulders, supported by gra$\mathrm{vel} / \mathrm{sandy} /$ clay matrix. Towards the east, there are several very large limestone olistoliths, up to $1 \mathrm{~km}$ across (Fig. 13; see also Yudin, 2009). Thin-sections of these limestones from the lowermost part of the conglomeratic complex contain the Oxfordian and Kimmeridgian microfossil assemblages (Appendix 1). It suggests that these conglomerates cannot be older than Kimmeridgian and younger than Berriasian. However, since the the Lower Jurassic flysch sediments and transported to the Sudak Basin together with reworked microfossils.

From the Vesele section (WP 18), we continued our observations along the road to Novyi Svit (Fig. 17). North of the road we passed the Khart-Kaya (375 $\mathrm{m}$ a.s.I.), a very large block (1 km across) of Upper Jurassic limestones. According to Yudin (2009) the block is incorporated into mélange $(\mathrm{m} 2)$. It is highly probable that this block is one of the many large olistoliths in the Upper Jurassic/Lower Cretaceous debris-flow conglomerates. Deposits with huge olistoliths are well exposed on a cliff edge towards Novyi Svit (e.g., the Koba-Kaya cliff; Fig. 17A) - see the Callovian/Oxfordian carbonate reef massif (Nikishin et al., 2015b), and on the cliff close to the lighthouse in Novyi Svit (Fig. 17B). On the southern slope of the massif, along the road, and directly below the conglomerates, carbonate sedimentary breccia (Fig. 17C) is exposed. The limestone block contains large Pecten shells (Fig. 10D), and ammonite (Fig. 17E) and ?stromatoid casts. This suggests that they can represent a redeposited biohermal facies. One of the samples taken from grey shale intercalations (sample WP 115) yielded a relatively rich assemblage of Lower Cretaceous (Neocomian) foraminifera (Appendix 1). Just below the road, there are strongly disturbed grey-greenish mudstones devoid of microfossils and fragments of limestones, which probably represent sedimentary breccias, without mesostructures characteristic for breccias of tectonic origin. From this section, Sheremet et al. (2016a) reported Upper Jurassic/Valanginian calcareous nannoplankton (points 66 and 67).

Pryvitne-Krasnolisia transect (Figs. 18 and 19). In this area, our research was carried out along a local road over a distance of $\sim 10 \mathrm{~km}$. The cross-section begins $\sim 7 \mathrm{~km}$ from the coastline of the Black Sea and runs northward through Pryvitne towards the main ridge of the $\mathrm{CM}$, up to Krasnolisia (Bilohirsk direction). According to previous studies in this loca- 

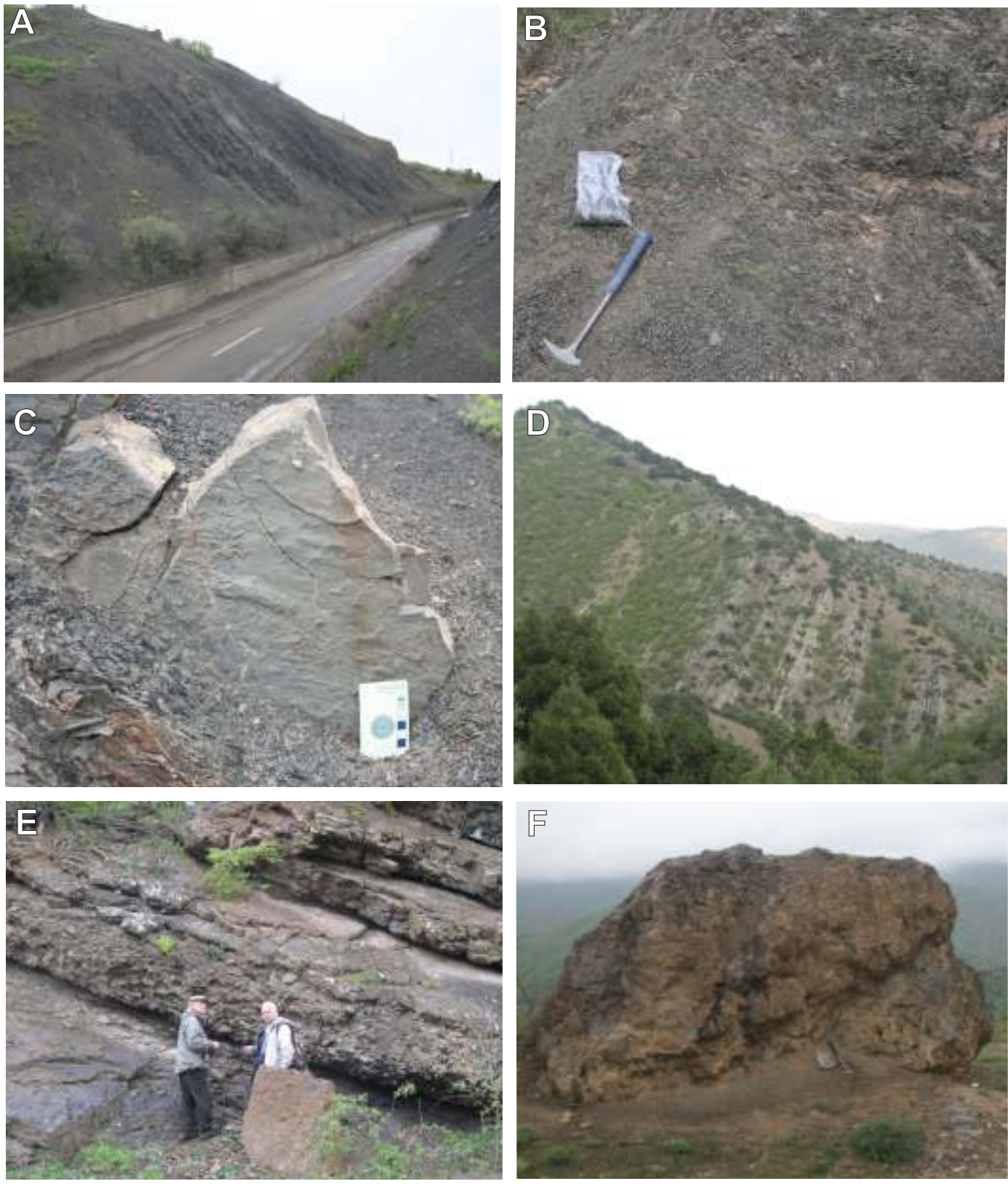

Fig. 15. Relation of the Early Cretaceous debris flow conglomerates to their flysch bedrock in the Vesele section

A - view from the road on the southern slope of Perchem-Kaya (576 $\mathrm{m}$ a.s.I.) with very thick, NW-dipping flysch series of TFF?; $\mathbf{B}$ - thin- to medium-bedded turbidites of TFF, roadcut; $\mathbf{C}$ - dark grey calcareous mudstones (sample WP 23); D - vertically dipping medium-bedded fine-grained sandstone, view on the lower surface with flute marks; E - ?Middle Jurassic/?volcanic olistolith (a few metres across) within dark grey shales (samples WP 18 and $18 \mathrm{~A}) ; \mathbf{F}$ - graded debris-flow conglomerates and thick-bedded sandstones of the basal part of the Upper Jurassic/?Lower Cretaceous transgressive series, northern side of road

tion (Pivovarov and Derenyuk, 1984; Bilecki, 2006b; Mileev et al., 2006; Afanasenkov et al., 2007; Yudin, 2009), the coastal plain, up to $8 \mathrm{~km}$ wide, is composed mainly of the TFF. According to Pivovarov and Derenyuk (1984), Upper Triassic-Lower Jurassic flysch deposits in this area are overlain by the Middle Jurassic flysch with intercalations of gravelites and lenses of coal. After Yudin (2009) the costal band of the TFF $\left(T_{3}-J_{2}\right)$, $\sim 3-4 \mathrm{~km}$ wide, is limited from the $\mathrm{S}$ and $\mathrm{N}$ by melange zones composed of the lower $\left(T_{3}-J_{1}\right)$ and upper $\left(T_{3}-J_{2}\right)$ parts of the
TFF, followed by a narrow zone of the Middle Jurassic sandstone/claystone flysch $\left(\mathrm{J}_{2}\right)$.

In this place, our transect (Fig. 18) starts with strongly tectonized black and dark grey shales, mudstones and thin- to medium-bedded sandstones (Figs. 18 and 19A, B). These beds are substantially similar to the upper part of the TFF $\left(T_{3}-J_{2}\right)$ and barren in microfossils (WP 122). In a conglomerate layer of WP 125 (Figs. 18 and 19C), we recognized a block of dark rudstone with the species of Troglotella incrustans Wernli and Fookes 

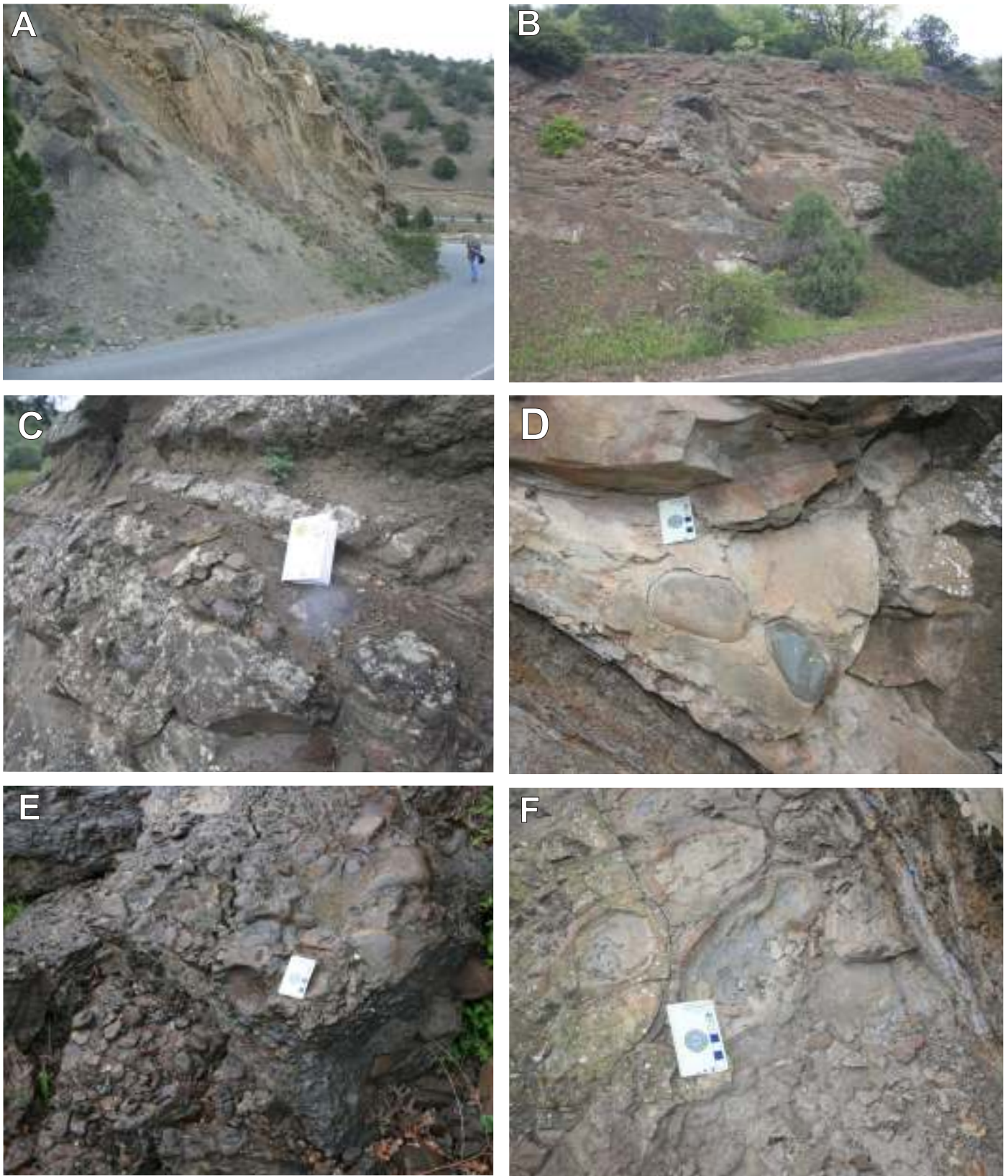

Fig. 16. Upper Jurassic/Lower Cretaceous conglomerate series in the Vesele road section

A - fine conglomerates at the base of sub-vertically dipping thick-bedded turbidite sandstones; $\mathbf{B}$ - thick-bedded sandstone and laminated mudstones at the base of a few metres-thick sequence of channel deposits; $\mathbf{C}$ - submarine slump conglomerates capped by laminated mudstones; D - matrix-supported debris flow with well-rounded cobbles; E - poorly sorted matrix-supported conglomerates; $\mathbf{F}$ - chaotically organized matrix-supported conglomerate

and microproblematic Koskinobullina socialis (Cherchi and Schroeder) suggesting an age not older than Kimmeridgian. Upper Aptian calcareous nannoplankton has recently been reported from a site located $2 \mathrm{~km}$ to the east of WP 125 (see Sheremet et al., 2016a: points 22 and 23, table 3). Higher up along our transect, folded dark flysch with intercalations of conglomerates is observed up to WP 134 (Fig. 18), where the flysch deposits are overlain by a very thick complex, up to $1000 \mathrm{~m}$ thick, of sedimentary breccias and conglomerates building up the main range of the mountains (Fig. 19D-E). They represent mainly various types of submarine slump deposits, debris-flow deposits (debrites with large olistostromes of Upper Jurassic micritic limestones), as well as thick-bedded turbidites, which commonly display channelization. Conglomeratic sequences are separated by few turbiditic sequences with medium- to thick-bedded sandstones and dark grey mudstones or shales, which are few metres thick. The Pryvitne conglomerate complex is overlain by a sequence of thin- and medium-bedded sandstones, several tens of metres thick, with thin intercalations of shales (Figs. 18 and 19F). Microfossils identified in the investigated samples (WP 100 and 149) suggest a Tithonian-Berriasian age or more likely Berriasian age (see Appendix 1). 

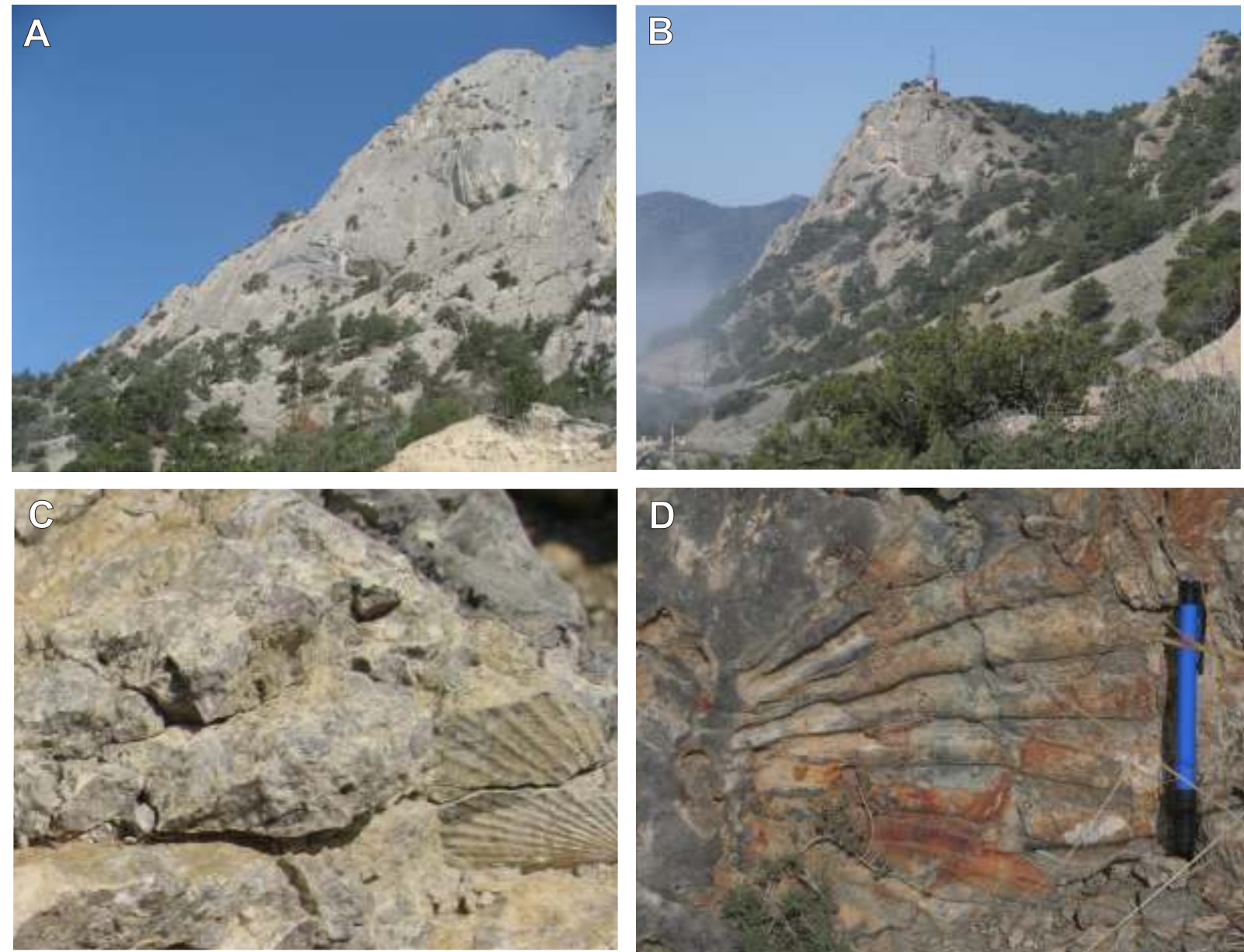

Fig. 17. Debris-flow thick-bedded conglomerates and olistoliths of Upper Jurassic reef limestones along the cliff in Novy Svit

A - seashore cliff along a road to Novyi Svit; SW-dipping conglomerates with several huge blocks of rocks at the top (Koba-Kay Callovian reef limestones; see Nikishin at al., 2015b); B - western view of the Novyi Svit seashore cliff, the Novyi Svit lighthouse, and a thick series of channelized Jurassic/Lower Cretaceous conglomerates; $\mathbf{C}$ - limestone block with a cast of brachiopod shell;

D - cast of a Jurassic ?ammonite in a large limestone boulder of Jurassic/Lower Cretaceous conglomerates

$\mathrm{N}$

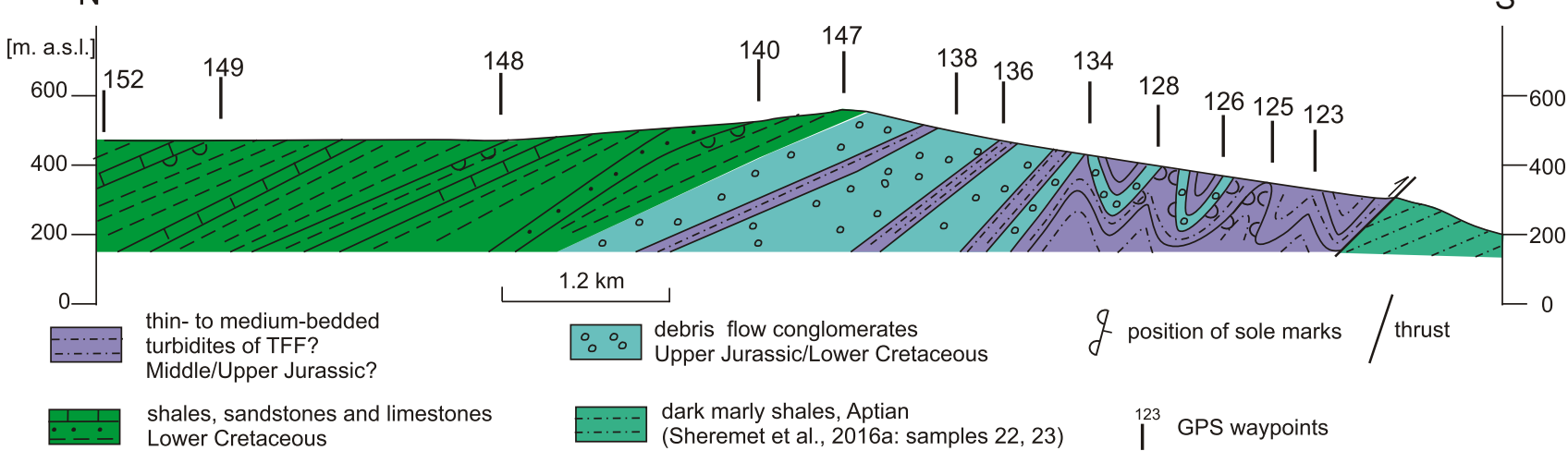

Fig. 18. Geological cross-section Pryvitne-Bilohirsk 

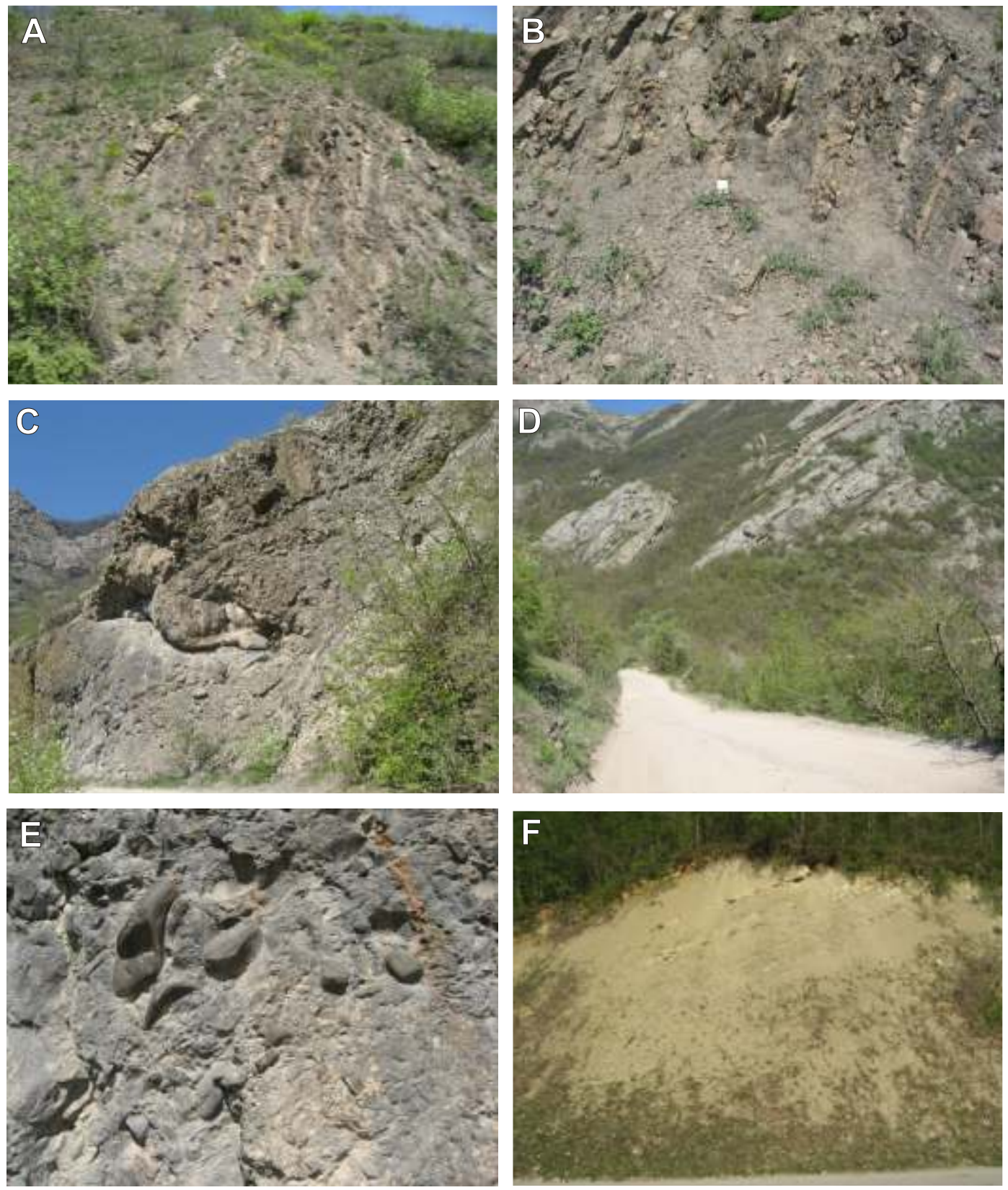

Fig. 19. Typical lithofacies along the Pryvitne-Bilohirsk transect

A - thin- to medium-bedded flysch of ?Taurida type, a narrow strongly deformed anticline (WP 123); B ?Taurida-type flysch at the base of debris-flow conglomerates; $\mathbf{C}$ - thick-bedded conglomerates with boulders and blocks of limestones; D - fining-upward conglomerate sequence near the pass; $\mathbf{E}$ - well-imbricated boulders and cobbles of conglomerates with sandy/gravelly matrix; $\mathbf{F}$ - Cretaceous flyschoid deposits with limestone intercalations, directly above the top of conglomerates, behind the pass (WP 149)

Further along the profile there is a sequence of thin- to thick-bedded turbiditic sandstones and dark grey mudstones with sporadic intercalations of very thick channelized conglomerates. On the map of Pivovarov and Derenyuk (1984) these deposits are regarded as Tithonian/Berriasian. Recently, Sheremet et al. $(2014,2016 a)$ included these beds into the Upper Jurassic/Valanginian. Our samples (WP 99a and b) confirm the Lower Cretaceous age (Lower Berriasian - sample 99a;
Upper Barremian - sample WP 99b; Appendix 1). Further towards the north, the next samples WP 151a and b, taken from a redeposited conglomerate block within grey mudstones, contain a foraminiferal assemblage of Tithonian age (Appendix 1). It ought to be stressed that these samples represent redeposited material and the Tithonian age is related to the primary age of sediments before subsequent reworking. 


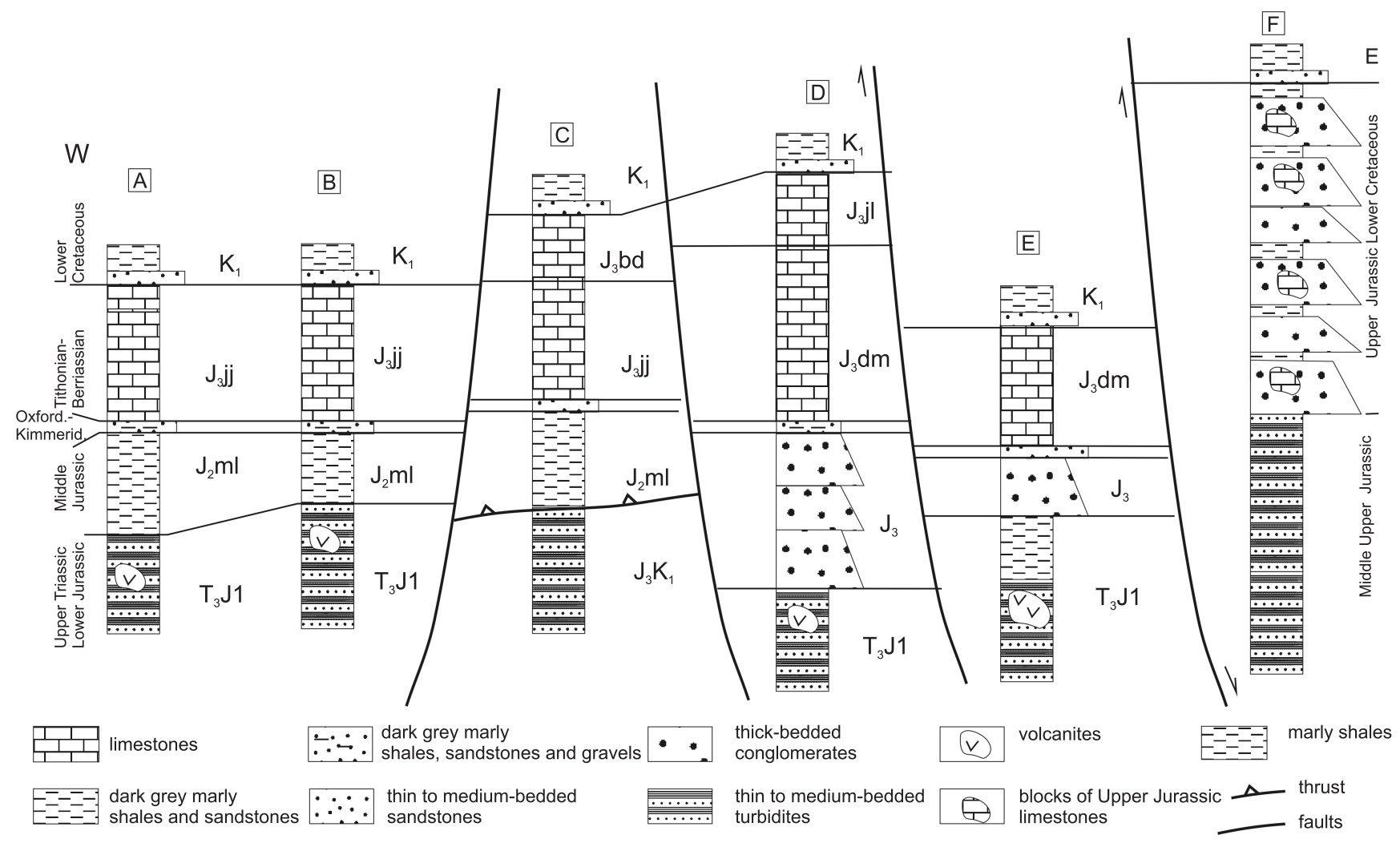

Fig. 20. Correlation of Mesozoic sediments along the Black Sea coast

A - southern termination of the Kacha Uplift; B - Laspi Area; C - Ay-Petri and Yalta massifs, Dimerji Yayla; D - Karabi Yayla; E - eastern sector of the CM, east of Pryvitne; F - eastern sector of the CM, Vesele-Novyi Svit-Sudak

\section{INTERPRETATION}

\section{RELATIONSHIP OF THE TFF} TO THE YOUNGER DEPOSITS OF THE CM

Our observations and published data on the relationship of the TFF with younger deposits indicate that in the NW sector of the CM (Kacha Uplift) up to the Alushta-Salgir-Simferopol Fault Zone, the TFF is transgressively overlain by the Lower Cretaceous, mainly Hauterivian, deposits (Pivovarov and Derenyuk, 1984; Bilecki, 2006b; Yudin, 2009, Sheret et al., 2014, 2016a; see also Figs. 3 and 4). It suggests that this area was emerged and intensely eroded during the Late Jurassic/Berriasian. A different situation is observed along the western coastal part of the CM (Figs. 3, 4 and 20). Between the Sarych Cap and Berehove, strongly deformed TFF, followed by Middle Jurassic deposits on the elevation up to $250-300 \mathrm{~m}$ a.s.l.; occurs in a narrow zone. In some places, there are small sub-volcanic dykes and sills, related to the Middle Jurassic volcanism (Bilecki, 2006a). In this area, the TFF is overlain by the Middle Jurassic Melask $\mathrm{Fm}$. followed by the Oxfordian/Kimmeridgian correlative horizon, $\sim 50$ m thick (see Oszczypko et al., 2012b, c). This unit could be partly correlated with both the Hurzuf (Bilecki, 2006a) and Sudak corelation horizons (see Leshchukh et al., 1999).

Towards the east, in the Berehove-Yalta uplifted block, we recognized the Upper Jurassic flysch (Lower Cretaceous according to Sheremet et al., 2016a), overthrust by the Upper Jurassic carbonate deposits of the Ay-Petri-Yalta Massif (Krajewski and Olszewska, 2007; Krajewski, 2010).
Between Yalta and Alushta, along the shoreline, the TFF again reveals numerous intrusions of the Middle Jurasic volcanites. The largest intrusion ( $3 \times 4 \mathrm{~km}$ ) of gabbro/basalts is located near Hurzuf (Ayu-Dag, see Bilecki, 2006b; Yudin, 2009). There are also large Middle Jurassic intrusions of gabbro/diabases and plagiogranites in this area (e.g., Kastel; Bilecki, 2006b; Solov'ev and Rogov, 2010).

In the post-Albian period, the Alushta-Salgir tectonic zone was transformed into the SE-dipping thrust fault that moved the Chatyr Dag Massif by at least $10 \mathrm{~km}$ to the west. East of this fault zone, the TFF narrows and then completely disappears near the village of Morske (Pivovarov and Derenyuk, 1984; Bilecki, 2006b; Yudin, 2009). Between the Sarych Cup and Alushta the TFF is overlain by the Middle Jurassic siltstone/claystone formations, 250-300 m thick (Fig. 20; see also Bilecki, 2006a, b). The lower part of the sequence belongs to the Belbek Fm. (S margin of the Kacha Uplift) and the Melaskaya Fm. (Laspi and Yalta/Ay-Petri sections), whereas the top of the sequence is included in the Ay-Vasil Formation.

East of Alushta, the position of the Middle Jurassic series is occupied by the Upper Jurassic conglomerates, up to $800 \mathrm{~m}$ thick (Lalomov, 2003, 2007). These conglomerates discordantly overlie the TFF and are covered by Tithonian/Berriasian carbonate platforms of the Demerji Yayla (cf. Bilecki, 2006b). Similar conglomerates, described by Bilecki (2006b) as the Tapshan $\left(\mathrm{J}_{2} \mathrm{~h} 3 \mathrm{tp}\right)$ or Khutoran beds $\left(\mathrm{J}_{3} \mathrm{ht}\right)$, are also found below the Chatyr-Dag and Karabi-Yayla carbonate platforms (Fig. 20). In both sections, the lower, red part of the conglomerates is of continental origin. These deposits probably represent alluvial river system cones derived from the NW (granitoids from the Ukrainian Shield, see Lalomov, 2007). Upper in the section the 
red conglomerates are replaced by grey debris-flow conglomerates deposited in a submarine coastal fan delta (Lalomov, 2007) or a Gilbert-type delta (Baraboshkin and Piskunov, 2010). The Demerji fan delta is a kind of half-graben cut by the Simferopol/Alushta Fault from the west, and edged to the east (Nikishin et al., 2015b).

Along the coastline, between the Sarych Cap in the west and Pryvitne in the east, the TFF $\left(T_{3}-J_{1}\right)$, followed by Middle Jurassic and Oxfordian/Kimmeridgian deposits, are overlain by the Tithonian/Berriasian carbonate platform. The thickness of this platform ranges from $\sim 500 \mathrm{~m}$ in the west (Sarych, Laspi), $\sim 800 \mathrm{~m}$ in the Ay-Petri Massif, $1300 \mathrm{~m}$ in Demerji, and $\sim 500 \mathrm{~m}$ in Karabi yaylas in the east. The Tithonian/Berria- sian carbonate platform (Zhabina, 2008; Zhabina and Anikeyeva, 2008) is regarded as a regional correlative horizon of the Main Ridge of the CM, transgressively overlain by the Valanginian/Hauterivian deposits. Near the village of Pryvitne, the Korabi carbonate platform disappears. On the map of Pivovarov and Derenyuk (1984), this boundary can be interpreted as a NW-SE scissor fault. In this interpretation, the NW wing of faults is occupied by the Valanginian-Hauterivian carbonate/marly deposits, while in the SE wing of the fault, the Jurassic/Cretaceous conglomerates and flysch occur. In a similar way, the map of Yudin (2009) can be interpreted. In the interpretation of Sheremet et al. (2016a), the fault zone has a NE-SW direction.

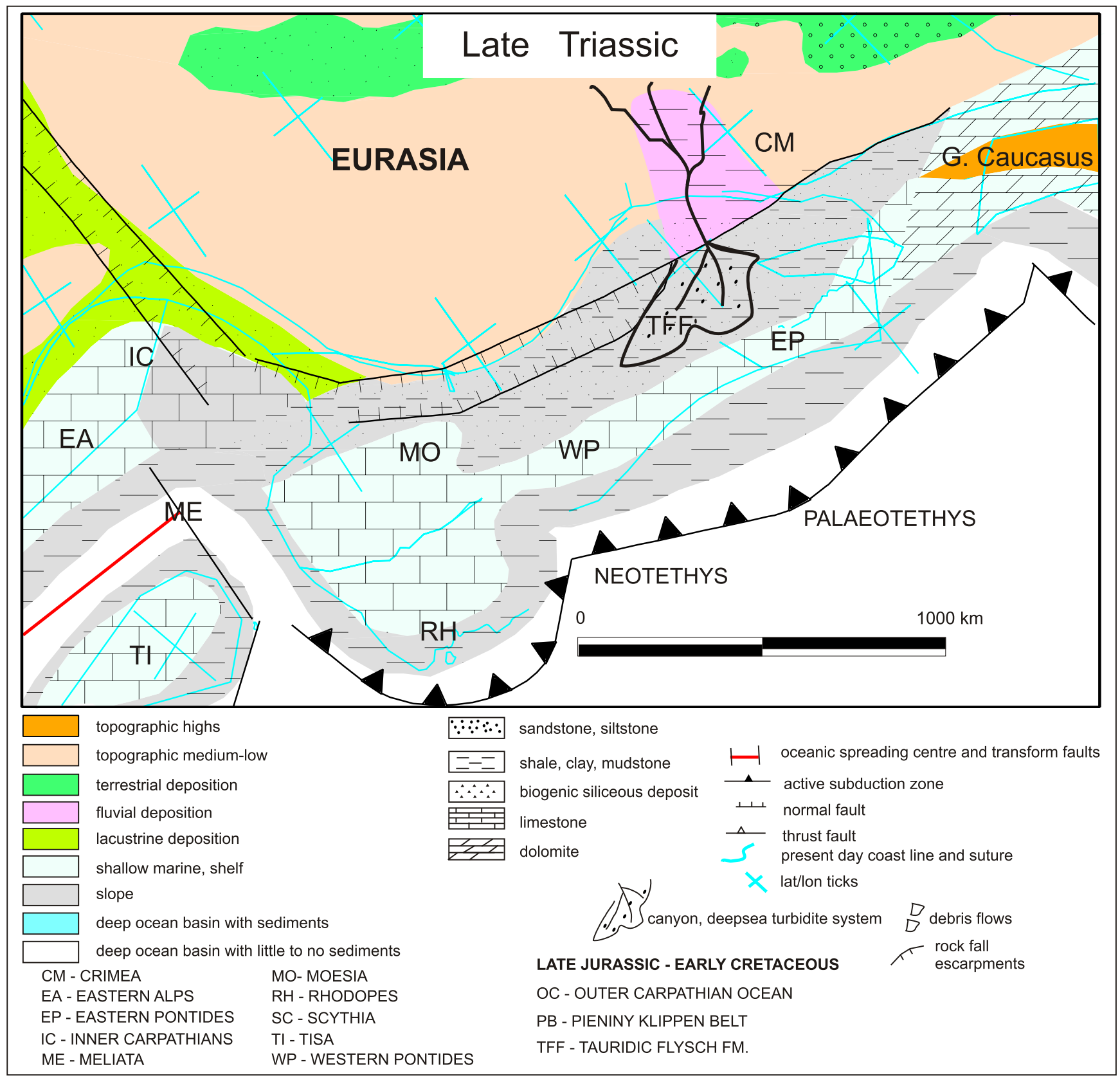

Fig. 21. The Late Triassic palaeotectonic position and lithofacies of the southern margin of Eurasia 


\section{PALAEOGEOGRAPHICAL RECONSTRUCTION}

During the Late Triassic/Early Jurassic (plate position at $225 \mathrm{Ma}$ ), the Taurida Flysch basin was located in the back-arc position (Golonka, 2004). This basin occupied the southern slope of the Scythian platform and the Pontide deep-water basin (Fig. 21). The measurements of palaeotransport directions in the Bodrak Valley show supply of clastic material from the NW. During the Early Jurassic (Nikishin, 2015b), marly/clay sediments were deposited in the northern, shallow-water part of the basin, locally followed by the accumulation of Lower/Middle Jurassic mudstones and claystones with coal-bearing intercalations (Pivovarov and Derenyuk, 1984; Bilecki, 2006a; Vergelska, 2016). This was followed by the Middle Jurassic folding, uplift and volcanic activity in the northern sector of the CM. According to Kruglov and Tsypko (1988), the folding and uplift were connected with the Early Cimmerian phase and took place only in the outer (WW) part of the Crimea Basin, while in the inner (SE) part of this basin, deep-water sedimentation persisted to the Early Cretaceous.

In the northwestern, folded and uplifted part of Crimea, erosion processes controlled the development of the river network, which supplied the Chatyr-Dag-Demerji alluvial cone, with clastic material derived from erosion of the uplifted Scythian Platform (Lalomov, 2003, 2007). The width of this cone, could reach $50 \mathrm{~km}$. During the Oxfordian marine transgression from the south, the alluvial cone in the north was gradually transformed into a marine fan delta. During the Kimmeridgian/Tithonian, this transgression resulted in the development of an extensive sea bay. Northwards (Demerji-Zuya), this bay might have reached a width of $60 \mathrm{~km}$. Towards the west the bay probably narrowed to $\sim 20 \mathrm{~km}$. A carbonate platform developed in this bay and in the adjacent shelf area. High subsidence rate of this area in the period $\sim 15$ My allowed the deposition of carbonate sequence, up to $1500 \mathrm{~m}$ thick. At the same time, the present-day Kacha Uplift was probably still emerged and eroded.

It is unclear what happened at that time in the eastern sector of the CM. Perhaps, during the Middle Jurassic, parallel with the uplift of the north-western sector of the $\mathrm{CM}$, the residual flysch basin moved eastwards of the Pryvitne, to the Sudak Trough. It was followed by the Late Jurassic/Early Cretaceous rifting (Stovba et al., 2013) and intense subsidence in the eastern sector of the CM, which obtained a connection with the sedimentary area of the Great Caucasus (Fig. 22). Simultaneously, a new source area appeared on the NW margin of the

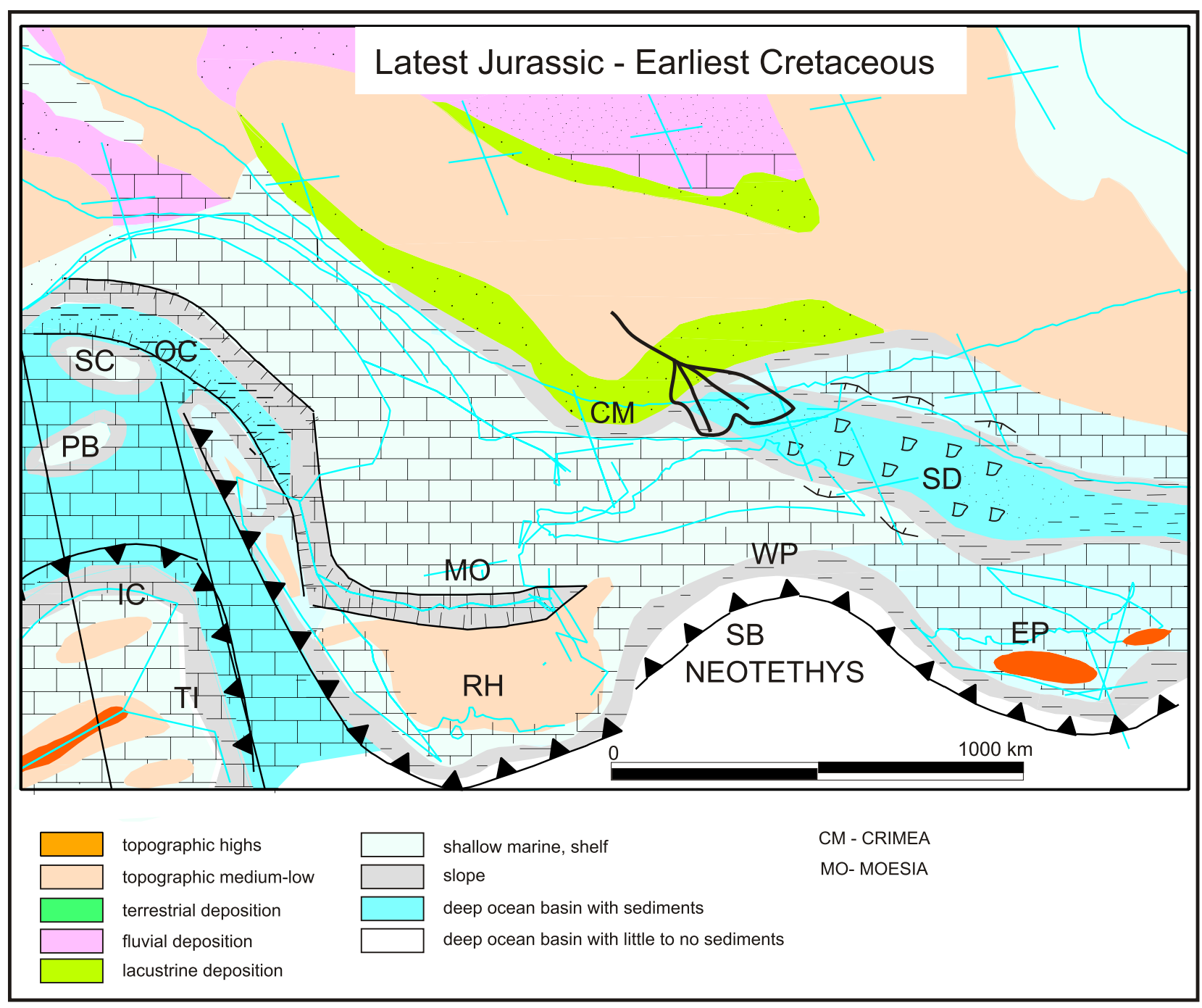

Fig. 22. The Late Jurassic-Early Cretaceous palaeotectonic position and lithofacies of the southern margin of Eurasia 
Sudak Trough. During the Late Jurassic and Early Cretaceous, that area supplied the basin with a huge amount of clastic material transported by turbidite and debris flows. At the same time, an active fault zone developed at the boundary between the eastern margin of the carbonate platform and the Sudak Trough. This zone generated significant landfalls of Upper Jurassic limestones derived to the Sudak Through as olistoliths and olistostromes. This resulted in progressive westward narrowing of the eastern sector of the carbonate platform, at least over a distance of $\sim 10 \mathrm{~km}$. Destruction of the carbonate platform was terminated with the beginning of the Valanginian/Hauterivian marine transgression.

\section{DISCUSSION}

Our results indicate the existence of at least two flysch formations in the CM: the Upper Triassic-Lower/?Middle Jurassic and the Upper Jurassic/Lower Cretaceous ones. In addition, the Aptian/Albian flysch-like deposits might have been locally deposited. The oldest foraminiferal assemblages that contain the species Thuramminoides metensis (Terquem) and rare Thalmannammina canningensis Tappan were found in several samples of brown and dark grey ferruginous siltstones intercalated by turbiditic sandstones from the Bodrak Valley, commonly regarded as belonging to the TFF. These species are known only from the Late Triassic/Early Jurassic. No younger species have been found. Samples of the TFF also show no traces of reworked species. Two samples (WP 11,12) from this locality contain stratigraphically significant calcareous dinocysts: Nannoceratiopsis senex and $N$. gracilis, which indicate Early Jurassic age. There is also one sample (WP 16) that contains Wallodinium laganum, characteristic for the Late Toarcian-Early Aalenian (see Oszczypko et al., 2012c).

To the south-east of the Kacha Uplift, three TFF samples (WP 32, 34, 35) of brown and dark grey ferrugineous siltstones contain Thuramminoides metensis (Terquem) of Late Triassic/Early Jurassic age. A similar assemblage with Thalmannammina canningensis Tappan and Hyperammina aff. pediformis Scherp was found near the Husynyi Hotel (WP 39). This foraminiferal assemblage suggests an Early Jurassic age. Rocks of the same age were found also to the east, in the Vesele section (WP 18 and 23), within beige micaceous mudstone regarded as a Lower Jurassic part of the TFF.

Near Sanatorne and Laspi, along the western part of the Black Sea coast, we found dark grey flysch, significantly different from that of the Bodrak Valley. In this area (WP 39/40; Figs. 1,2 and $3 \mathrm{~B}$ ) the foraminiferal assemblages typical of Late Triassic and Early Jurassic included Hyperammina aff. pediformis Scherp (WP 39) indicating Toarcian age. In addition, the TFF is overlain in this area by the Middle Jurassic flyschoid formations (Ay-Vasil and Belbek) with a total thickness of up to $500 \mathrm{~m}$ (Fig. 20; see also Bilecki, 2006a, b, 2007). The above-described sequence of flysch and flyschoid sediments is overlain by the Oxfordian/Kimmeridgian transgressive deposits, identified at the base of the Tithonian/Berriasian carbonate platform (Oszczypko et al., 2012b, c). This confirms unequivocally the Upper Triassic-Lower/Middle Jurassic position of the TFF in this part of the CM. To the east of Yalta, the Middle Jurassic flyschoid deposits are replaced over a distance of $\sim 25 \mathrm{~km}$ by a large submarine conglomeratic fan (Fig. 20; see Upper Jurassic Conglomeratic Formation, UJCF of Lalomov, 2007) of uncertain age, but recently regarded as Oxfordian and Kimmeridgian-Tithonian (Baraboshkin and Piskunov, 2010).
A definitely different geological and stratigraphic interpretation of the Prokhladne area was presented by Popadyuk et al. (2013) who, based on small foraminifera, included the TFT of the Bodrak Valley into the Albian. That paper also provides information about a finding of the Albian-Cenomanian foraminifer Gumbelina cenomanica Agal in the Mender borehole at Prokhladne, at a depth of 94-200 m (Yanin, 1976). With this in mind, we want to recall that Marcinowski and Najdin (1976) reported the Upper Albian ammonites from several sections near Prokhladne and gave information about a borehole drilled in the training centre MGU (Geological Faculty of Moscow University). In this drilling, Upper Albian red marly mudstones occur down to a depth of $85 \mathrm{~m}$, underlain by Lower Jurassic deposits of the Taurida Formation at a depth of 85-90 m.

East of the Karabi Yayla and north of Pryvitne, our investigations have confirmed the presence of another younger submarine conglomeratic fan system (Tithonian) deposited by different density currents, which can represent a coarse flysch sequence. The base of these conglomerates is clearly visible in both the Pryvitne and Vesele sections.

In the Privitne section, the conglomeratic sequence, not younger than Berriasian, is underlain by strongly deformed dark grey thin- to medium-bedded flysch, similar to the TFF but not older than Kimmeridgian (WP 122-125). Previously-mentioned flysch is regarded as Middle Jurassic (Pivovarov and Derenyuk, 1984) or Late Triassic-Early Jurassic in age (Yudin, 2009). Similarly, we can interpret the position of the volcanic block (WP 18) from the Vesele section, underlain and overlain by dark siltstones, as Lower Jurassic at the base (WP 18) and Upper Jurassic/Lower Cretaceous (WP 18A; Appendix 1) at the top. These siltstones are separated by a volcanic block. In such situation the Lower/Middle Jurassic foraminifera at the base of volcanites (WP 23 and 18) should be regarded as reworked.

In the Novyi Svit section, at the base of conglomerates with large blocks of Upper Jurassic reef limestone, there are Lower Cretaceous dark marly shales (WP 115) similar to that of the Sudak Flysch. The age of the Pryvitne and Vesele conglomerates, overlain by the Lower Cretaceous shaly flysch facies (WP 149, 99 and 151), may be estimated as Tithonian/Berriasian, while the Novyi Svit conglomerates may belong to the Lower Cretaceous.

At several localities in the eastern sector of the $\mathrm{CM}$, calcareous nannoplankton not younger than Valanginian has recently been determined (Sheremet et al., 2014, 2016a). The same younger dates (Hauterivian and Barremian) were obtained by Pivovarov and Derenyuk (1984).

There are at least two flysch sequences within the CM: (1) upper Triassic-Lower/Middle Jurassic, known from the western sector of the CM as the TFF, and (2) Upper Jurassic/Lower Cretaceous, developed east of the Pryvitne-Bilohirsk line and typical for the eastern sector of the CM. The Upper Jurassic/Lower Cretaceous flysch of the Sudak Formation passes upwards into a thick unit of conglomerates and sandstones with blocks and large olistoliths of Upper Jurassic limestones, deposited by submarine avalanches and high-density turbiditic currents (Khart-Kaya Fm.). This sequence is terminated by the Lower Cretaceous flyschoid marly deposits.

Unclear is the geotectonic position occupied by a complex of dark marly claystones and turbidites, exposed along the road from Simferopol to Alushta. In the northern part of the area, Pivovarov and Derenyuk (1984) distinguished the Albian claystones that occupied a narrowing to the south bay (see also Marcinowski and Najdin, 1976). Recently, in the southern extensions of this bay, Popadyuk et al. (2013a, b) documented the Albian deposits, and Sheremet et al. (2014, 2016a) found Up- 
per Aptian-Lower Barremian rocks. Further to the south, at the northern edge of the Chatyr-Dag Yayla (WP 101) and along a road (WP 107), we found the Albian dark marls and turbidites, formerly regarded as the TFF (Pivovarov and Derenyuk, 1984; Bilecki, 2006b; Yudin, 2009). In our opinion, the Aptian/Albian deposits recently found in the TFF area along the western edge of the Dolhorukovska Yayla could be related to the Aptian/Albian marine transgression onto the TFF (Kacha Uplift, see Marcinowski and Najdin, 1976; Pivovarov and Derenyuk, 1984). A similar stratigraphic position is occupied by the Upper Aptian-Albian deposits near Zelenohorye, and by the Barremian-Hauterivian rocks in Berehove, Yalta, and close to the Demerji Yayla (Sheremet et al., 2016a).

\section{CONCLUSIONS}

1. At least two flysch formations are found in the Crimea Mts.: the Taurida (Upper Triassic to Lower/?Middle Jurassic) of the western sector of the CM, and the Upper Jurassic to Lower Cretaceous flysch of the Sudak Formation (eastern sector of the CM). The Upper Jurassic/Lower Jurassic flysch deposits has been also recognized near Berehove, the west of the Yalta. These deposits probably are prolonged along the shoreline towards the east.

2. Additionally, the Middle Jurassic flyschoid deposits were also accumulated (e.g., the Belbek and Ay-Vasil formations) in the western sector of the $\mathrm{CM}$.

3. Along the Black Sea between Sevastopol and Alushta, above the TFF and beneath the Late Jurassic carbonate platform, the Upper Oxfordian/Kimmeridgian Laspi correlative hori- zon has been documented. It is partly an equivalent of the Hurzuf and Sudak horizons.

4. At the base of the Late Jurassic carbonate platform (Chatyr-Dag, Demerji and Karabi) and above the TFF, there are the Middle/Upper Jurassic alluvial and delta fan conglomerates derived from the NW.

5. During the Late Jurassic/Early Cretaceous, the deep-water Sudak Basin developed to the east of Pryvitne, supplied with coarse-grained deposits sourced from the NW. These sediments were transported by debris and density turbiditic flows. It is not excluded that the deposits could provide the slope facies of the flysch basin.

6 . The basin was simultaneously supplied with large blocks (olistoliths) of Upper Jurassic limestones, derived from destruction of the eastern edge of the Karabi carbonate platform.

7. Majority of melanges distinguished in the $\mathrm{CM}$, due to the homogeneity of their material, are not true melanges, but rather strongly tectonized "broken formations", olistostromes and so-called "chaotic" sedimentary deposits.

Acknowledgements. Our research in the Crimea Mts. was conducted under a grant of the Polish National Science Centre, titled "Position and age of the "Black Flysch" in the Carpathian-Alpine orogen and the Crimea Mts." (N N 307 256139). Dr A. Murovska (Kiev, Ukraine), Prof. M. Sosson (Valbonne, France) and an anonymous reviewer provided critical comments on the early versions of the text. Dr E. Gedl (Kraków, Poland) determined calcareous dinocyts. Thanks are also due to Prof. J. Golonka (Kraków, Poland) for discussions, and Dr Y. Volfman (Yalta, Ukraine) for discussion and organization of fieldwork (2011).

\section{REFERENCES}

Adamia, S.A., Chkhotua, T., Kekelia, M., Lordkipanidze, M., Shavishvili, I., Zakariadze, G., 1981. Tectonics of Caucasus and adjoining regions: implications for the evolution of the Tethys ocean. Journal of Structural Geology, 3: 437-447.

Afanasenkov, A.P., Nikishin, A.M., Obukhov, A.N., 2007. Geologicheskoye stroyeniye i uglevodoronnyi potentsial Vostochno-Chernomorskovo regiona (in Russian). Nauchnyi Mir.

Albov, S.W., 1964. Deyaki dani pro paleozoik v Krymu (in Russian). Geologichnyi Zhurnal, 24: 73-78.

Astakhova, T.V., 1968a. Nekotorye karniyskiye ammonidei Kryma (in Russian). Paleontologicheskiy Sbornik, 5: 81-86.

Astakhova, T.V., 1968b. Noryiskiye ammonidei Kryma (in Russian). Paleontologicheskiy Sbornik, 5: 45-51.

Astakhova, T.V., 1971. Triasovye dvusvorchatyye i golovonogiye molusky Kryma (in Russian). Kiev, Naukowa Dumka.

Astakhova, T.V., 1972. Paleontologicheskaya kharakteristyka triasovykh otlozheniyi Kryma (in Russian). Paleontologicheskiy Sbornik, 9: 57-63.

Astakhova, T.V., 1976. Pervaya nakhodka srednietriasovogo amonita iz tavrichetckoy svity Gornogo Kryma (in Russian). Geologicheskiy Zhurnal, 36: 131-134.

Baraboshkin, E.Y., 1997. A new stratigraphic classification of the Lower Cretaceous deposits in the Kacha-Bodrak interfluve (Southwestern Crimea) (in Russian with English summary). Moscow University Geology Bulletin, 52: 19-37.

Baraboshkin, E.Y., Piskunov, V.K., 2010. Composition and condition of forming of the Upper Jurassic depositions of the region of
Pahkal-Kaya (Crimea) (in Russian with English summary). Vestnik MGU, Series, 4, Geologiya, 1: 17-25.

Bilecki, C.B., ed., 2006a. Derzhavna gelogichna karta Ukrainy, 1:200 000, arkushi L-36-XXVIII (Eupatoriya), L-36-XXXIV (Sevastopol). Krymska seria (in Ukrainian). Kyiv: Derzhavna Geologiczna Sluzhba «Pivdenekogeocentr».

Bilecki, C.B., ed., 2006b. Derzhavna gelogichna karta Ukrainy, 1:200 000, arkushi L-36-XXIX (Simferopol), L-36-XXXV (Yalta). Krymska seria (in Ukrainian). Kyiv: Derzhavna Geologiczna Sluzhba «Pivdenekogeocentr».

Bilecki, C.B., ed., 2007. Derzhavna gelogichna karta Ukrainy, 1:200 000, arkushi L-36-XXIX (Simferopol), L-36-XXXV (Yalta). Krymska seria (in Ukrainian). Kyiv: Derzhavna Geologiczna Sluzhba «Pivdenekogeocentr».

Bocaletti, M., Gocev, P., Manetti, P., 1974. Mesozoic isotopic zones in the Black Sea region. Bolletino della Societa Geologica Italiana, 93: 547-565.

Bolotov, S.N., Panov, D.I., Yaroshenko, O.P., 2004. New data on palynological characteristics of Triassic and Liassic of Bodrak River basin (in Russian with English summary). Byulleten Moskovskogo Obshchestva Ispytateley Prirody, Otdeleniye Geologii, 76: 13-20.

Byzova, S.L., 1980. Nekotorye voprosy tektoniki Gornogo Kryma (in Russian). Vestnik Moskovskogo Universiteta, Seriya B, 4: 15-25.

Dekhtyareva, L.V., Nerodenko, V.M., Komarova, O.V., Mihaylova, I.A., 1978. About the nature of the horizon of limestone blocks in the outskirts of Simferopol (in Russian with English summary). 
Proceedings of the Academy of Sciences of the USSR, 3 64-67.

Derenyuk, N.E., ed., 1984. Geologicheskaya Karta Gornogo Kryma 1: 200000 (in Russian). Ministerstvo Geologii USSR, Kiev.

Dorotyak, Yu.B., 2008. Foraminifera complexes of the Tithonian-Berriasian boundary in the Mountain Crimea (in Russian with English summary). In: Biostratyhrafichni osnovy pobudovy stratyhrafichnykh skhem fanerozoyu Ukrayiny (ed. P.F. Hozhyk) 78-82. Zbirnyk Naukovykh Prats Instytutu Heolohichnykh Nauk NAN Ukrainy, Nora-Print, Kyiv.

Dubois de Montpereaux, D., 1837. Lettre sur les principaux phenomenes geologiques du Caucasus et de la Crimmee adresse a M. Elie de Beaumont. Bulletin de la Societe Geologique de France, 8

Galkin, V.A., Fedorov, Y.V., Bakhor, K., 1994. The interrelationships and structure of the Upper Jurassic and Lower Cretaceous deposits in the Salgir river Valley (Central Crimea) (in Russian with English summary). Transactions of the Russian Academy of Science, Earth Science Section, 326: 55-60.

Golonka, J., 2004. Plate tectonic evolution of southern margin of Eurasian in the Mesozoic and Cenozoic. Tectonophysics, 381: 235-273.

Hurskiy, D.S., Kruglov, S.S., eds., 2007. Tectonic map of Ukraine. Scale 1:1000 000. Explanation notes. Part 1. Ministry of Ecology and Natural Resources. Government Geological Survey. Ukrainian Government Geological Prospecting Institute, Kyiv, UkrDGRI.

Ippolitov, A.P., Tishhenko, A.P., Rogov, M.A., Alekseev, A.S. Beko, M., 2008. About finding lumps of Upper Toarcian limestones near Simferopol and its significance for interpretation of geological structure of the Crimean Mountains (in Russian). In: New Regional Geology in Russia and Abroad: Proceedings of Meeting. Moscow, RSGPU Publ.: 43-46.

Kazantsev, Y.V., 1982. Tektonika Kryma (in Russian). Nauka, Moscow.

Kazantsev, Y.V., Kazantceva, T.T., Arzhavitina, M.Y., Arzhavitin P.V., Beher, N.I., Terehov, A.A., Popovich, S.V., 1989. Structural Geology of the Crimea (in Russian). Bashkir Scientific Center of Ural Department of the Academy of Science of the USSR, Ufa.

Kazmin, V.G., Schreider, A.A., Bulychev, A.A., 2000. Early stages of evolution of the Black Sea. Geological Society Special Publications, 173: 235-249.

Klikushyn, W.G., 1988. Triasovye i rannoyurskiye krinoidea Kryma (in Russian). Byulleten Moskovskogo Obshchestva Ispytateley Prirody, Otdeleniye Geologii, 63: 71-79.

Koronovsky, N.V., Mileev, V.S., 1974. On the relation between deposits of Tauric series and Eski Orda suite in the Bodrak Valley (the Crimea Mountains) (in Russian with English summary). Vestnik MGU, Series 4, Geologiya, 1: 80-87.

Krajewski, M., 2010. Facies, microfacies and development of the Upper Jurassic-Lower Cretaceous of the Crimean carbonate platform from Yalta and Ay-Petri massifs (Crimea Mountains), Southern Ukraine. Dissertations Monographs, 217: 5-252.

Krajewski, M., Olszewska, B., 2007. Foraminifera from the Late Jurassic and Early Cretaceous carbonate platform facies of the southern part of the Crimea Mountains, Southern Ukraine. Annales Societatis Geologorum Poloniae, 77: 291-311.

Kruglov, S.S., Tsypko, A.K., 1988. Tektonika Ukrainy (in Russian). Nedra, Moskva.

Lalomov, A.V., 2003. Flood geology of the Crimean Peninsula, Part II: conglomerate and gravel sandstones of the Demerji Formation. Creation Research Society Quarterly, 40: 17-23.

Lalomov, A.V., 2007. Reconstruction of paleohydrodynamic conditions during the formation of Upper Jurassic conglomerates of the Crimean Peninsula. Lithology and Mineral Resources, 42 268-280.

Leshchukh, R.J., Permyakov, V.V., Polukhtovich, B.M., 1999. Jurassic deposits of the southern Ukraine (in Ukrainian). Eurosvit, Lviv.

Letouzey, J., Biju-Duval, B., Dorkel, A., Gonnard, R., Kristchev, K., Montadert, L., Sungurlu, O., 1977. The Black-Sea: a mar- ginal basin: geophysical and geological data. In: Structural History of the Mediterranean Basin (eds. B. Biju-Duval and L. Monatader): 363-376. Editions Technip, Paris.

Levitskiy, E.S., 1974. The fossil Decapoda crustaceans near Bakhchisaray (Crimea) (in Russian). Byulleten Moskovskogo Obshchestva Ispytateley Prirody, Otdeleniye Geologii, 49: 3-22.

Marcinowski, R., Najdin, D.P., 1976. An Upper Albian amonite fauna from Crimea. Acta Geologica Polonica, 26: 83-101.

Meijers, M.J.M., Vrouwe, B., van Hinsbergen, D.J.J., Kuiper, K.F., Wijbrans, J., Davies, G.R., Stephenson, R.A., Kaymakcı, N., Matenco, L., Saintot, A., 2010. Jurassic arc volcanism on Crimea (Ukraine): implications for the paleo-subduction zone configuration of the Black Sea region. Lithos, 119: 412-426.

Mileev, V.S., Rozanov, S.B., Baraboshkin, E.Ju., Shalimov, I.V., 1997. The tectonic structure and evolution of the Crimea Mountains (in Russian). Geological Faculty, MGU, Moscow, 265 187-206.

Mileev, V.S., Baraboshkin, E.Y., Rozanov, S.B., Rogov, M.A., 2006. Cimmerian and Alpine tectonics of the Mountain Crimea (in Russian with English summary). Byulleten Moskovskogo Obshchestva Ispytateley Prirody, Otdeleniye Geologii, 81: 22-33.

Mileev, V.S., Baraboshkin, E.Yu., Rozanov, S.B., Rogov, M.A., 2009. Tectonics and geodynamic evolution of Mountain Crimea (in Russian with English summary). Byulleten Moskovskogo Obshchestva Ispytateley Prirody, Otdeleniye Geologii, 84: 3-22.

Muratov, M.V., 1960. Kratkiy ocherk geologicheskogo stroyeniya Krymskogo poluostrova (in Russian). Gos. Nauch.-Tekh. Izd-vo Literatury po Geologii i Okhranie nedr, Moskva.

Muratov, M.V., ed., 1969. Geology of the USSR, 8, The Crimea, Part I, Geological Description (in Russian). Nedra, Moscow.

Muratov, M.V., 1972. Istoria formirovania glubokovodnoy kotloviny Chornogo moria v sravnienienii c Sredniomoskim (in Russian). Geotektonika, 5: 22-41.

Muratov, M.V., Archipov, I.V., Uspenskaya, E.A., 1984. Structural evolution of the Crimea in comparison to the West Caucasus in the Eastern Balkans (in Russian with English summary). Byulleten Moskovskogo Obshchestva Ispytateley Prirody, Otdeleniye Geologii, 59: 3-10.

Nikishin, A.M., Cloetingh, S., Brunet, M.-F., Stephenson, R.A., Bolotov, N., Ershov, A., 1998. Scythian Platform, Caucasus and Black Sea region: Mesozoic-Cenozoic tectonic history and dynamics. Memoires Museum National D'histoire Naturelle, 177: 163-176.

Nikishin, A.M., Okay, A., Tuysüz, O., Demirer, A., Wannier, M., Amelin, N., Petrov, E., 2015a. The Black Sea basins structure and history: new model based on new deep penetration regional seismic data. Part 2: Tectonic history and paleogeography. Marine and Petroleum Geology, 59: 656-670.

Nikishin, A.M., Wanniert, M., Alekseev, A.S., Almendinger, A. Fokin, P.A., Garbullin, R.R., Khudoley, A.K., Kopaevich, L.F, Mityukov, A.V., Petrov, E.I., Rubtsova, E.V., 2015b. Mesozoic to recent geological history of southern Crimea and Eastern Black Sea region. Carleton University Library on November, 3 $1-23$.

Okay, A.I., Altiner, D., Kilic, A.M., 2015. Triassic limestones, turbidites and serpentinite - the Cimmeride orogeny in the central Pontides. Geological Magazine, 152: 460-479.

Oszczypko, N., Malata, E., Švabenicka, L., Golonka, J., Marko, F., 2004. Jurassic-Cretaceous controversies in the Western Carpathian Flysch: "black flysch" case study. Creteceous Research, 25: 89-113.

Oszczypko, N., Olszewska, B., Malata, E., 2012a. Cretaceous (Aptian/Albian-?Cenomanian) age of "black flysch" and adjacent deposits of the Grajcarek thrust-sheets in the Małe Pieniny Mts. (Pieniny Klippen Belt, Polish Outer Carpathians). Geological Quarterly, 56 (3): 411-440.

Oszczypko, N., Ślączka, A., Bubniak, l., Olszewska, B., 2012b. Remarks on age of the Tauridic flysch series of the Crimea Mountains (Ukraine). 2nd International Conference "Alpine-Petrol 2012", 25-28 September, 2012 Kraków, Poland. Abstract book: $49-50$. 
Oszczypko, N., Ślączka, A., Bubniak, I., Olszewska, B., Gedl, E., 2012c. Early stages of the Crimean Mountains development (Ukraine): a new approach. In: Conference of Environmental, Structural and Stratigraphical Evolution of the Western Carpathians, December 6-7, 2012 (eds. S. Jozsa, D. Rehakova and R. Vojtko): 34. Abstract Book. Fac. Nat. Sc., Comenius University, Bratislava.

Panek, T., Danisik, M., Hradecky, J., Frisch, W., 2009. Morpho-tectonic evolution of the Crimean mountains (Ukraine) as constrained by apatite fission track data. Terra Nova, 21: 271-278.

Panov, D.I., Bolotov, S.N., Nikishin, A.M., 2001. Scheme of the stratigraphic subdivision of the Triassic and Lower Jurassic deposits of the Crimea Mountains (in Russian with English summary). In: Geodynamics and Petroleum Systems of the Black Sea-Caspian Region: Proceedings of the III International Conference Crimea-2001, 17-21 September 2001, Gursuf. Tavriia Plus, Simferopol: 127-134.

Pivovarov, S.V., Derenyuk, N.E., 1984. Geological Map of the Crimean Mountains at a Scale of 1:200 $000 \mathrm{Kiev}$ (in Russian). UkrSSR Ministry of Geology, Kiev.

Popadyuk, I.V., 2011. Crimea Mountains: the inversion? of what? Abstracts of the 3rd International Symposium on the Geology of the Black Sea Region. Bucharest, Romania: 137-140. http://cretaceous.ru/files/pub/baraboshkin_ea_2011_crimea_romania.pdf

Popadyuk, I.V., Smirnov, S.E., 1991. Problem of the structure of the Crimea Mountains - traditional conceptions and reality (in Russian with English summary). Geotectonica, 25: 489-497.

Popadyuk, I.V., Khriachtchevskaia, O.I., Stovba, S.M., 2010. Geology of the Crimea Mountains in the context of petroleum explorations in the Black Sea. AAPG European Regional Conference and Exhibition, Kiev, Ukraine, Guidebook to field trip, No. 1. Ukraine. http:// cretaceous.ru/files/pub/collections/guides/popaduk 2010 guid pdf.

Popadyuk, I.V., Stovba, S.M., Khriachtchevskaia, O.I., 2013. The new geological map of the Crimea Mountains by SPK Geoservice as a new approach to understanding the Black Sea Region. In: Abstracts of Darius Programme, Eastern Black Sea - Caucasus Workshop (eds. M. Sosson and S.H. Adamia) 48-50. 24-25 June 2013, Tbilisi, Georgia, http://cretaceous.ru/ files/pub/temp/popadyuk_et_al2013-new_geolog_map_of_crimea.pdf

Popadyuk, I.V., Stovba, S.M., Khryashchevskaya, O., 2014. A few comments on the article Sheremet, Y., Sosson, M., Gintov, O. Muller, C., Yegorova, T., Murovskaya, Key problems of stratigraphy of the eastern part of Crimea Mountains. New micropalentological data on flysch rocks (in Russian). Geophysical Journal, 36: 35-56.

Shcherba, I.G., 1978. Pliocene-Quaternary olistostromes of the Crimea and mechanism of their origin (in Russian). Byulleten Moskovskogo Obshchestva Ispytateley Prirody, Otdeleniye Geologii, 53: 23-34.

Sheremet, Y., Sosson, M., Gintovt, O., Muller, C., Yegorova, T., Murovskaya, A., 2014. Key problems of stratigraphy of Crimea Mountains. New micropalentological data on flysch rocks (in Russian with English abstract). Geophysical Journal, 36: 35-56.

Sheremet, Y., Sosson, M., Muller, C., Gintov, O., Murovskaya, A. Yegorova, T., 2016a. Key problems of stratigraphy in the Eastern Crimea Peninsula: some insights from new dating and structural data. Downloaded from http://sp.lyellcollectio.org/ at Dogu Technik Universitesi on April 9, 2016.

Sheremet, Y., Sosson, M., Ratzov, G., Sydorenko, G., Voitsitskiy, Z., Yegorova, T., Gintovt, O., Murovskaya, A., 2016b. An offshore-onland transect across the north-eastern Black Sea basin (Crimean margin): evidence of Paleocene to Pliocene two-stage compression. Tectonophysics, 688: 84-100.

Solov'ev, A.V., Rogov, M.A., 2010. First fission-track dating of zircons from Mesozoic complexes of the Crimea. Stratigraphy and Geological Correlation, 18: 298-306.
Sosson, M., Rolland, Y., Müller, C., Danelian, T., Melkonyan, R., Kekelia, S., Adamia, S., Babazadeh, V., Kangarli, T., Avagyan, A., Galoyan, G., Mosar, J., 2010. Subductions, obduction and collision in the Lesser Caucasus (Armenia, Azerbaijan, Georgia), new insights. Geological Society, Special Publications, 340: 329-352.

Sosson, M., Stephenson, R., Sheremet, Y., Yann Rolland, Y., Adamia, S., Melkonian, R., Kangarli, T., Yegorova, T., Avagyan, A., Galoyan, G., Danelian, T., Hässig, M., Meijers, M., Müller, C., Sahakyan, L., Sadradze, N., Alania, V., Onice Enukidze, O., Mosar, J., 2016. The eastern Black Sea-Caucasus region during the Cretaceous: new evidence to constrain its tectonic evolution. Geoscience, 348: 23-32.

Stovba, S.M., Khriachtchevskaia, O.I. Popadyuk, I.V., 2013. Crimea and Ukrainian Eastern Black Sea Basin as an inverted Early Cretaceous rift system. Abstracts of Darius Programme, Eastern Black Sea - Caucasus Workshop (eds. M. Sosson and S.H. Adamia): 48-50. 24-25 June 2013, Tbilisi, Georgia, http://cretaceous.ru/ files/pub/temp/stovba et al2013

Vergelska, N., 2016. Middle Jurassic coals of the Mountainous Crimea: a potential source rock offshore Ukraine? Petroleum Systems of Alpine-Mediterranean Fold Belts and Basins, European Regional Conference and Exhibition, 19th-20th May, 2016 Bucharest, Romania: 76-77.

Yanin, B.T., 1976. New data about geological structure of Bakhchisaray region of the Crimea (in Russian). Vestnik Moskovskogo Universiteta, Seriya B, 5: 41-50.

Yudin, V.V., 2001. The geological structure of Crimea on the basis of actual geodynamics (in Russian with English summary). In: Suppplement to the Collection of Papers-Aspects of Crimea Evolution. Crimea Academy of Sciences, Simferopol.

Yudin, V.V., 2005. Preliminary results of drilling of Simferopolskaya well-1 (in Russian). In: Geodinamics, seismicity, Oil and Gas Content of Black sea-Caspian Region "Crimea-2005". Smferopol: $75-77$.

Yudin, V.V., 2009. Geologicheskaya karta i razrezy Gornogo, Predgornogo Kryma 1:200 000 (in Russian). Soyuzkarta, Simferopol.

Yudin, V.V., 2010. Geodynamic evolution and structural complexes of the Crimea. AAPG Search and Discovery Article 90109, 2010 AAPG European Region Annual Conference, October 17-19, 2010 Kiev, Ukraine.

Yudin, V.V., 2013. Geology of Simferopol in geodynamic of Crimea. Sbornik nauchnykh trudov "Ot mineralogii dp geokhimii". Kiev: 207-217, http: //museumkiev.org/Geology/ conf/fersman.pdf

Yudin, V.V., Arkadiev, V.V., Yurovsky, Yu.G., 2015. "Revolution" in geology of Crimea (in Russian with English summary). Viestnik SPGU, 7: 25-37.

Zhabina, N.M., 2008. Tintinid systematics and distribution in the Upper Jurassic-Neocomian deposis of the Tethys (in Russian with English abstract). In: Biostratyhrafichni Osnovy Pobudovy Stratyhrafichnykh Skhem Fanerozoyu Ukrainy (ed. P.F. Hozhyk): 87-92. Zbirnyk Naukovykh Prats Instytutu Heolohichnykh Nauk NAN Ukrainy, Nora-Print, Kyiv.

Zhabina, N.M., Anikeyeva, O.V., 2008. Microscopical characteristic of reef deposits in Mountain Crimea (in Russian with English abstract). In: Biostratyhrafichni Osnovy Pobudovy Stratyhrafichnykh Skhem Fanerozoyu Ukrainy (ed. P.F. Hozhyk): 83-86. Zbirnyk Naukovykh Prats Instytutu Heolohichnykh Nauk NAN Ukrainy, Nora-Print, Kyiv.

Zonenshain, L.P., Le Pichon, X., 1986. Deep basins of the Black Sea and Caspian Sea as remnants of Mesozoic back-arc basins. Tectonophysics, 123: 181-211.

Zonenshain, L.P., Kuzmin, M.I., Natapov, L.M., 1990. Plate Tectonics in the USSR, 2 (in Russian with English summary). Nedra, Moscow. 